Front Biosci. ; 13: 5323-5344.

\title{
Role of oxidative stress and nitric oxide in atherothrombosis
}

\author{
Edith Lubos, Diane E. Handy, and Joseph Loscalzo \\ Department of Medicine, Brigham and Women's Hospital, and Harvard Medical School, Boston, 75 \\ Francis Street, Boston, Massachusetts 02115
}

\begin{abstract}
During the last decade basic and clinical research has highlighted the central role of reactive oxygen species (ROS) in cardiovascular disease. Enhanced production or attenuated degradation of ROS leads to oxidative stress, a process that affects endothelial and vascular function, and contributes to vascular disease. Nitric oxide (NO), a product of the normal endothelium, is a principal determinant of normal endothelial and vascular function. In states of inflammation, NO production by the vasculature increases considerably and, in conjunction with other ROS, contributes to oxidative stress. This review examines the role of oxidative stress and NO in mechanisms of endothelial and vascular dysfunction with an emphasis on atherothrombosis.
\end{abstract}

\section{Keywords}

Oxidative Stress; Antioxidants; Endothelial Dysfunction; Atherothrombosis; Review

\section{INTRODUCTION}

The generation of reactive oxygen species (ROS) is important in both normal physiology and in the pathogenesis of many diseases. The ROS include partially reduced forms of molecular oxygen, such as hydroxyl radical $\left({ }^{\circ} \mathrm{OH}\right)$, superoxide anion $\left(\mathrm{O}_{2}{ }^{-\bullet}\right)$, hydrogen peroxide $\left(\mathrm{H}_{2} \mathrm{O}_{2}\right)$, lipid peroxides, and hypochlorous acid ( $\mathrm{HClO})$. Accumulation of ROS may be accompanied by the production of reactive nitrogen species (RNS), such as the highly reactive peroxynitrite anion, a strong oxidant formed by the reaction of $\mathrm{O}_{2}{ }^{\bullet}$ and nitric oxide (NO). Under physiological conditions, cells defend themselves against ROS damage through antioxidants that remove free radical intermediates and inhibit oxidation. An imbalance between endogenous oxidants and antioxidants results in oxidative stress, a condition that contributes to vascular dysfunction and atherogenesis (1).

Superoxide anion is generated by the one-electron reduction of oxygen by nicotinamide adenine dinucleotide (phosphate) $(\mathrm{NAD}(\mathrm{P}) \mathrm{H})$ oxidase, mitochondrial respiration, and other oxidoreductases, such as glucose oxidase and xanthine oxidase $(2,3)$. The effects of $\mathrm{O}_{2}{ }^{-\bullet}$ include oxidative damage, the mediation of signal transduction leading to altered gene transcription, posttranslational modification with changes in protein function and enzyme activity ('redox signaling'), and rapid inactivation of NO, leading to endothelial dysfunction. Alterations in both the rate of formation and the extent of scavenging of $\mathrm{O}_{2}^{-\bullet}$ have been

Send correspondence to: Joseph Loscalzo, M.D., Ph.D., Brigham \& Women's Hospital, 75 Francis Street, Boston, MA 02115, Tel: 617-732-6340, Fax: 617-732-6439, E-mail: jloscalzo@partners.org.

Note that the International Union of Pure and Applied Chemistry (IUPAC) recommended names for peroxynitrite anion $\left(\mathrm{ONOO}^{-}\right)$, peroxynitrous acid $(\mathrm{ONOOH})$, and nitric oxide $(\mathrm{NO})$ are oxoperoxonitrate $\left(1^{-}\right)$, hydrogen oxoperoxonitrate, and nitrogen monoxide respectively. The term, peroxynitrite, is used here to refer to the sum of both $\mathrm{ONOO}^{-}$and its conjugated acid, $\mathrm{ONOOH}$. 
implicated in the vascular dysfunction observed in atherosclerosis, hypertension, diabetes mellitus, chronic nitrate tolerance, and postischemic myocardial dysfunction $(4,5)$.

In the endothelium, $\mathrm{NO}$ is synthesized by the $\mathrm{Ca}^{2+}$-calmodulin-dependent nitric oxide synthase (eNOS), using L-arginine, $\mathrm{O}_{2}$, and NADPH as substrates (6). Nitric oxide is membrane permeable and diffuses throughout the vasculature, promoting smooth muscle cell relaxation by activation of soluble guanylyl cyclase and modulation of cation channels, and, consequently, regulating vascular tone (7). Additional antiatherogenic actions of $\mathrm{NO}$ relate to inhibition of platelet function and inflammatory cell adhesion, promotion of fibrinolysis, and attenuation of smooth muscle cell proliferation (8). Nitric oxide and $\mathrm{O}_{2}{ }^{-}$react in a diffusion-controlled process to produce peroxynitrite, which interacts directly with lipids, DNA, and proteins, or indirectly through downstream radical-medicated mechanisms.

In the setting of cardiac risk factors and pathological conditions such as atherothrombosis, oxidative stress is associated with impaired NO bioavailability (9-11). Endothelial dysfunction represents the earliest stage in the atherosclerotic process, and also contributes to the pathogenesis of acute vascular syndromes by predisposing to plaque rupture and intravascular thrombosis. In this review, we present an overview of oxidative stress, NO synthesis, and biological chemistry, as well as the evidence linking the pathophysiology of endothelial dysfunction and atherothrombosis.

\section{REACTIVE OXYGEN SPECIES}

\subsection{Sources of reactive oxygen species}

During aerobic respiration, mammalian cells produce energy by reducing molecular oxygen $\left(\mathrm{O}_{2}\right)$ to water $\left(\mathrm{H}_{2} \mathrm{O}\right)$. As a natural byproduct of normal metabolism, ROS play a regulatory part in cellular function (Table 1). These highly reactive molecules have the potential to interact with and irreversibly damage proteins, lipids, and DNA; antioxidant defenses modulate their steady-state flux, thereby limiting their toxicities.

A variety of enzymatic and non-enzymatic sources of ROS, particulary of $\mathrm{O}_{2}{ }^{-\bullet}$, are present in cells of the vasculature. Endothelial cells, vascular smooth muscle cells, adventitial cells, and fibroblasts contain forms of the membrane-associated NAD(P)H oxidase enzyme complex that catalyze the one-electron reduction of molecular oxygen using $\mathrm{NAD}(\mathrm{P}) \mathrm{H}$ as an electron donor and the reduced form of $b_{558}$-type cytochrome, generating $\mathrm{O}_{2}{ }^{-}$(Figure 1) (12-18). Stimulators of $\mathrm{NAD}(\mathrm{P}) \mathrm{H}$ oxidase includes agonists of G-protein-coupled-receptors, such as angiotensin II and endothelin-1; bradykinin; growth factors, such as thrombin, vascular endothelial growth factor, and platelet derived growth factor; and cytokines, such as tumor necrosis factor-alpha (TNF-alpha) (13,19-23). Metabolic and mechanical factors, and nutrient deprivation can also increase $\mathrm{NAD}(\mathrm{P}) \mathrm{H}$ oxidase activity (24-26). $\mathrm{NAD}(\mathrm{P}) \mathrm{H}$ oxidase activity is increased during hypoxia-reoxygenation, reperfusion, prolonged exposure to nitroglycerin, and exposure to oxidized low-density lipoprotein (ox-LDL) (27-30). Activation involves modulation of membrane-bound non-phagocytic NAD(P)H oxidase (Nox) and $\mathrm{p} 22^{\text {phox }}$ subunit expression, and cytosolic regulatory subunits, namely $\mathrm{p} 67^{\text {phox }}, \mathrm{p} 47^{\mathrm{phox}}, \mathrm{p} 40^{\mathrm{phox}}$, and the small GTPase Rac1 (17,31). Endothelial cells contain the isoforms Nox-1, Nox-2 (gp91 $\left.{ }^{\text {phox }}\right)$, Nox-4, and Nox-5; vascular smooth muscle cells express Nox-1, Nox-4, and Nox-5; and advential fibroblasts and vascular smooth muscle cells from resistance arteries contain Nox-2 (32-36). Acute increase in oxidase complex formation occurs secondary to post-translational modification of regulatory subunits ( $\mathrm{p} 47^{\mathrm{phox}}$ and Rac1) or an increase in the expression and abundance of component subunits.

Another source of vascular $\mathrm{O}_{2}^{-\bullet}$ is the xanthine oxidoreductase (XOR) enzyme system, which consists of a ubiquitous metalloflavoprotein found in two forms, xanthine dehydrogenase (XD) 
and the posttranslationally modified form, xanthine oxidase (XO) (3). This enzyme system is expressed on the luminal surface of the endothelium and catalyzes the oxidation of hypoxanthine to xanthine in normal purine metabolism. XD requires $\mathrm{NAD}^{+}$as an electron acceptor; whereas XO reduces $\mathrm{O}_{2}$, thereby generating $\mathrm{O}_{2}{ }^{-}$. The conversion of XD to XO occurs either through the reversible thiol oxidation of cysteinyl residues or via an irreversible proteolytic cleavage of a segment of XD that can occur during hypoxia, ischemia, or inflammation (3). In addition, xanthine oxidase can directly donate two electrons to oxygen to produce $\mathrm{H}_{2} \mathrm{O}_{2}$. A marked increase in endothelial xanthine oxidase activity has been found following ischemia-reperfusion and hypoxia-reoxygenation (37). In hypercholesterolemic patients, the inhibition of xanthine oxidase activity with oxypurinol improved impaired vasodilation, suggesting $\mathrm{O}_{2}^{-\bullet}$ production by this enzyme can substantially reduce bioavailable NO under certain pathophysiological conditions (38).

A third potential source of vascular $\mathrm{O}_{2}^{-\bullet}$ in endothelial cells is the family of nitric oxide synthases (NOS) (39). The NOS enzymes are dimeric, calmodulin-dependent or calmodulincontaining cytochrome P450-like hemoproteins that combine reductase and oxygenase catalytic domains in one monomer, bear both FAD and FMN (flavin adenine nucleotide), and carry out a five-electron oxidation of one of the basic guanidino nitrogen atoms of $\mathrm{L}$-arginine with the reductive aid of tetrahydrobiopterin $\left(\mathrm{BH}_{4}\right)$, producing $\mathrm{NO}$ and L-citrulline (40). In the presence of suboptimal concentrations of $\mathrm{L}$-arginine or of the cofactor $\mathrm{BH}_{4}, \mathrm{NOS}$ is functionally 'uncoupled' and produces $\mathrm{O}_{2}{ }^{-\bullet}$ via one-electron reduction of molecular oxygen $(41,42)$. Similarly, peroxynitrite may also oxidize $\mathrm{BH}_{4}$ and thereby cause NOS uncoupling (43). Tetrahydrobiopterin repletion improves endothelial function in chronic smokers and augments NO bioactivity in normal, hypertensive, and hypercholesterolemic human subjects (44-46). Hypercholesterolemia is also associated with endothelial dysfunction in animal models as well as in human subjects (47-49). Treatment with L-arginine attenuates endothelial dysfunction in animal models; however, the ability of L-arginine to improve endothelial function in hypercholesterolemic or other human subjects is less clear, with some studies finding a benefit wherease others fail to show improvement in endothelial responses following L-arginine treatment (50-53). Peroxynitrite can also uncouple NOS by oxidizing cysteines involved in the zinc-thiolate cluster, releasing zinc and disrupting functional dimer stability (54).

Another mechanism of endothelial dysfunction that relates to eNOS substrate availability is the in vivo presence of NOS inhibitors, most importantly asymmetric dimethyl arginine (ADMA), a naturally occurring guanidino-substituted analog of L-arginine $(55,56)$. Elevated ADMA levels have been demonstrated in hyperhomocysteinemia, hypercholesterolemia, hypertension, atherosclerotic disease, and peripheral vascular disease, and correlate inversely with brachial artery flow-mediated vasodilation $(57,58)$.

Additional intracellular sources of ROS in the endothelium include an isoenzyme of cytochrome P450 (endothelium-derived hyperpolarizing factor synthase), cyclooxygenases, lipoxygenases, aldehyde oxidase, flavin dehydrogenases, and mitochondrial respiration (59-61). The mitochondrial electron transport chain produces $\mathrm{O}_{2}^{-\bullet}$ by incomplete reduction of $\mathrm{O}_{2}$, mainly at complex I (NADH coenzyme $\mathrm{Q}$ reductase) and complex III (ubiquinol cytochrome $c$ reductase) (61-62). These mitochondrial sites may also be important participants in oxygen sensing vascular redox signaling (63). Increased mitochondrial $\mathrm{O}_{2}{ }^{-\bullet}$ generation in endothelial cells appears to be particularly prominent in diabetes, ischemia-reperfusion injury, and hypoxia-reoxygenation (64-65).

\subsection{Effects of reactive oxygen species in the vasculature}

At physiological $\mathrm{pH}, \mathrm{O}_{2}^{-\bullet}$ is both a free radical and an anion (pKa 4.8) (66). Owing to its charge, $\mathrm{O}_{2}^{-\cdot}$ can be transported across biological membranes by anion channels, while its free 
radical character causes it to react with other radicals in the range of diffusion-controlled reactions (66). Its ability to participate in either electron-accepting oxidation reactions (with sulfydryl groups, ascorbic acid, NADPH) or electron-donating reduction reactions (with cytochrome $c$, metal ions) influences the vascular signaling system.

Superoxide anion reacts with itself to form $\mathrm{H}_{2} \mathrm{O}_{2}$ and $\mathrm{O}_{2}$ by spontaneous $\left(k=\sim 5 \times 10^{5} \mathrm{M}^{-1}\right.$. $\mathrm{s}^{-1}$ at $\mathrm{pH}$ 7.4) and enzymatic dismutation reactions (Figure 2) (67). The spontaneous dismutation rate is second order with respect to $\mathrm{O}_{2}{ }^{-\bullet}$ concentration. Basal levels of $\mathrm{H}_{2} \mathrm{O}_{2}$ appear to regulate some signaling systems thought to participate in oxygen and redox sensing, or are reduced to $\mathrm{H}_{2} \mathrm{O}_{2}$ by peroxiredoxins, glutathione peroxidases, or catalase (68). By the metalcatalyzed Fenton reaction, $\mathrm{H}_{2} \mathrm{O}_{2}$ forms the highly reactive ${ }^{\circ} \mathrm{OH}$, which is the strongest oxidizing agent known and reacts with organic molecules at diffusion-limited rates. Hydroxyl radical can modify amino acids, carbohydrates, lipids, and nucleic acids (69). Theoretically, owing to its interaction with ferrous complexes, $\mathrm{NO}$ prevents the formation of ${ }^{\circ} \mathrm{OH}$ by limiting the Fenton reaction $(70,71)$. Hydroxyl radical-induced endothelial injury inhibits both the production and activity of NO. Thus, NO and oxygen or oxygen-derived radicals can modulate NO bioactivity (72). Nitric oxide can be oxidatively inactivated to nitrite $\left(\mathrm{NO}_{2}^{-}\right)$(in a third-order reaction with $\mathrm{O}_{2}$ that is second-order in $\mathrm{NO}$ ) and nitrate $\left(\mathrm{NO}_{3}{ }^{-}\right)$, oxidation products that have been considered to be devoid of vasodilatory activity at physiological concentrations (73). Recent studies, however, suggest $\mathrm{NO}_{2}{ }^{-}$at physiological concentrations may function as a vasodilator, perhaps due, in part, to the nitrite reductase function of deoxyhemoglobin, or to the spontaneous reduction to NO under acidic, relatively hypoxic conditions in ischemic tissues (74-75).

Reactive oxygen species can potentiate vascular dysfunction. In small cerebral arteries, impairment of endothelial function by excessive production of free radicals during acute hypertension sets the stage for increased reactivity to vasoconstrictor stimuli and the production of contractile prostanoids $\left(\mathrm{PGG}_{2}, \mathrm{PGH}_{2}\right)$ in endothelial cells as well as in smooth muscle cells via oxidation of the ferric heme of cyclooxygenase (76-78). In arteries obtained from diabetic animals, decreased endothelium-dependent relaxation appears to be linked to enhanced release of $\mathrm{O}_{2}{ }^{-}$owing to excessive activation of arachidonic acid metabolism via cyclooxygenase $(79,80)$.

In angiotensin II-mediated hypertension, $\mathrm{NAD}(\mathrm{P}) \mathrm{H}$ oxidase activity plays an important role as a source of ROS and mediator of elevated blood pressure; both hypertension and NAD(P) $\mathrm{H}$ oxidase activation can be prevented by administration of the $\mathrm{AT}_{1}$-receptor antagonist losartan $(4,81)$. Other studies have shown that the expression of angiotensin converting enzyme $(\mathrm{ACE})$ is increased in atherosclerotic plaque, potentially resulting in increased local production of angiotensin II. ACE-inhibitors may act as antioxidants, in part, by limiting angiotensin IImediated $\mathrm{O}_{2} \cdot \bullet$ production, thereby decreasing blood pressure and improving vascular dysfunction $(82,83)$.

Reactive oxygen species may also modulate normal signaling pathways at multiple levels from membrane receptors and channels to various protein kinases and nuclear transcription factors $(84,85)$. An increase in $\mathrm{O}_{2}^{-\bullet}$ production is associated with an increase in cytoplasmic $\mathrm{Ca}^{2+}$ by enhanced extracellular $\mathrm{Ca}^{2+}$ influx and intracellular inhibition of $\mathrm{Ca}^{2+}$ uptake by the sarcoplasmatic reticulum (86). In smooth muscle cells, $\mathrm{O}_{2}{ }^{-\bullet}$ can inhibit inositol 1,4,5triphosphate-sensitive responses of the sarcoplasmic reticulum $\mathrm{Ca}^{2+}$-ATPase, which inhibits $\mathrm{Ca}^{2+}$ uptake (87). An increase in $\mathrm{Ca}^{2+}$ influx is a consequence of the reaction between ROS and thiol groups of the $\mathrm{L}$-type $\mathrm{Ca}^{2+}$-channels or by reaction with thiol-containing cysteine-rich groups of protein kinase $\mathrm{C}$ (PKC) (88). Activation of PKC regulates L-type $\mathrm{Ca}^{2+}$-channels by phosphorylation (89). An increase in intracellular $\mathrm{Ca}^{2+}$ concentration stimulates peroxynitrite formation, which may account for thiol group oxidation (nitrosation) of sarcoplasmatic reticulum cysteinyl side chains. In addition, ROS decreases voltage-dependent $\mathrm{K}^{+}$current 
density, possibly by oxidation of a methionine residue on the $\mathrm{K}^{+}$channel protein of coronary artery smooth muscle cells, leading to impairment of vascular function (90-91). Similarly, ROS also inhibits ATP-dependent $\mathrm{K}^{+}$currents in cardiac myocytes (92).

Oxidant species control several other signaling mechanisms in the vasculature, including soluble guanylyl cyclases (sGC), prostaglandin production, cerulopasmin, myeloperoxidase, and tyrosine kinase regulated systems (93-95). In smooth muscle cells, a prooxidant state promotes stimulation of mitogen activated protein kinases (p42/p44 MAPK or ERK 1/2) and tyrosine kinases (protein kinase B), which leads to cell growth and migration $(13,31)$. Stimulation of vascular smooth muscle cells by the mitogen platelet derived growth factor increases intracellular production of $\mathrm{H}_{2} \mathrm{O}_{2}$ and tyrosine phosphorylation; antioxidants, such as catalase and $\mathrm{N}$-acetylcysteine, have been shown to modulate this activation $(1,96)$. In the vasculature, this signaling pathway leads to hypertrophy and intimal thickening contributing to the progression of hypertension, to an increase in adhesion molecule expression, and to the development of atherosclerosis (11).

\section{ANTIOXIDANTS}

A paradox of metabolism is that while the vast majority of complex life requires oxygen for its existence, molecular oxygen is a highly reactive molecule that can damage living organisms by conversion to its partially reduced forms, the ROS (97). Consequently, organisms contain a complex network of low-molecular-weight antioxidant molecules and specific antioxidant enzymes that modulate redox state and prevent oxidative damage of cellular components. In general, antioxidant systems either prevent ROS from being formed, or remove them before they can damage vital components of the cell (98). Nonenzymatic antioxidant molecules in endothelial cells include uric acid, ascorbic acid (vitamin C), alpha-tocopherol (vitamin E), and glutathione (GSH), and are classified as hydrophilic or lipophilic (membrane-associated) (Table 2) (99).

Ascorbic acid is a water soluble monosaccharide that is maintained in its reduced form by GSH in a reaction that can be catalyzed by protein disulfide isomerase and glutaredoxins (100). Ascorbic acid scavenges ROS but, through its reductive effect on metal ions, can also contribute to free radical formation via the Fenton reaction (101-102). Ascorbic acid has a favorable redox couple that protects vitamin E and GSH from oxidation. In clinical studies, ascorbic acid supplementation improves NO-dependent vasodilation in human subjects with coronary artery disease, hypertension, hypercholesterolemia, and diabetes mellitus $(103,104)$.

Vitamin E is a lipid soluble, chain-breaking radical scavenger family of eight related tocopherols and tocotrienols, and is considered the most important antioxidant in cell membranes (105). Of the various forms, alpha-tocopherol has the highest bioavailability and protects cell membranes against oxidation by reacting with lipid radicals produced during lipid peroxidation chain reactions $(105,106)$. Oxidized alpha-tocopheroxyl radicals produced in this process may be recycled back to the active, reduced form through reduction by ascorbate, retinol, or ubiquinol (107). The function of the other forms of vitamin $E$ are less well-studied, although gamma-tocopherol is a nucleophile that may react with electrophilic mutagens, and tocotrienols may have a specialized role in neuroprotection $(106,108)$. Vitamin E may also have nonantioxidant cell signaling functions by modulating the activity of several enzymes involved in signal transduction (109). Owing to the antioxidant properties of vitamin E, vitamin E may improve endothelial function and reduce cardiovascular risk. Despite an initial small study demonstrating a therapeutic benefit of vitamin $\mathrm{E}$ on reducing non-fatal myocardial infarction, more recent, placebo-controlled, large-scale trials of antioxidants have been disappointing and have found no clinically benefical effects of long term vitamin $\mathrm{E}$ supplementation (110-113). 
GSH is the major low-molecular-weight cysteine-containing peptide found in most forms of aerobic life, and is synthesized in cells from its constituent amino acids (114-115). Glutathione has antioxidant properties as the thiol group in its cysteinyl moiety can be reversibly oxidized. In endothelial cells, GSH serves as a substrate for glutathione peroxidases to eliminate lipid hydroperoxides and $\mathrm{H}_{2} \mathrm{O}_{2}$, whereby it becomes oxidized to GSH disulfide (GSSG) (116). Depletion of endogenous GSH in ischemia-reperfusion and hypercholesterolemia may also alter the vascular wall's ability to detoxify peroxynitrite (117).

Important endothelial antioxidant enzymes include the superoxide dismutases (SODs), catalase, the thioredoxin system, peroxiredoxins, the glutathione peroxidases, and heme oxygenase. The SODs convert $\mathrm{O}_{2}^{-\bullet}$ to $\mathrm{H}_{2} \mathrm{O}_{2}$ which is then reduced to $\mathrm{H}_{2} \mathrm{O}$ by peroxiredoxins, catalase, or glutathione peroxidases; superoxide can also undergo spontaneous dismutation $\left(k=\sim 5 \times 10^{5} \mathrm{M}^{-1} \bullet \mathrm{s}^{-1}\right.$ at $\left.\mathrm{pH} 7.4\right)$. Vascular tissue contains three isoforms of SOD that enzymatically accelerate the dismutation of $\mathrm{O}_{2}^{-\bullet}\left(k=\sim 2 \times 10^{9} \mathrm{M}^{-1} \bullet \mathrm{s}^{-1}\right)(66,118-121)$. SODs contain metal ion cofactors that, depending on the isoenzyme, can be copper, zinc, manganese, or iron. Lack of metal ion binding can lead to significant enzyme instability, resulting in reduced enzyme levels and activity (122). Naturally occurring mutations of SOD and $\mathrm{H}_{2} \mathrm{O}_{2}$-mediated oxidation have been shown to interfere with metal ion binding, thereby reducing enzyme function and contributing to a pathological state (123).

Healthy cells can control the intracellular formation of $\mathrm{O}_{2}^{-\bullet}$ through the activities of cytosolic $\mathrm{Cu}, \mathrm{Zn}-\mathrm{SOD}$ (SOD 1) and mitochondrial Mn-SOD (SOD 2) (124). Cu,Zn-SOD expression is upregulated by shear stress and the cellular redox state (125). Mn-SOD expression is also redox-sensitive and can be induced by vascular endothelial growth factor via the activation of $\mathrm{NAD}(\mathrm{P}) \mathrm{H}$ oxidase. The extracellular form of $\mathrm{Cu}, \mathrm{Zn}-\mathrm{SOD}$ (EC-SOD or SOD 3 ) is produced by smooth muscle cells, tightly binds to heparan on the exofacial plasma membrane, and is particularly abundant in the interstitium of the arterial wall (126). Extracellular superoxide dismutase may be crucial for the vasodilating activity of extracellular NO by controlling the levels of extracellular $\mathrm{O}_{2}{ }^{-}$and preventing the formation of peroxynitrite. The balance between the $\mathrm{O}_{2}^{-\bullet}$-producing oxidases and SOD activities keeps basal $\mathrm{O}_{2}{ }^{-}$concentrations below the range in which this species can directly interfere with vascular signaling (85).

Catalase is a highly catalytically efficient enzyme that reduces $\mathrm{H}_{2} \mathrm{O}_{2}$ to water using either an iron or manganese cofactor (127). Catalase is mostly limited to peroxisomes located adjacent to mitochondria, and is expressed in higher levels in smooth muscle cells than endothelial cells (128).

Peroxiredoxins (Prx) represent a unique type of peroxidase that catalyze the reduction of $\mathrm{H}_{2} \mathrm{O}_{2}$, organic hydroperoxides, as well as peroxynitrite (129). Mammalian cells express six isoforms of Prx, which are classified into three subgroups (2-Cys, atypical 2-Cys, and 1-Cys) based on the number and positions of Cys residues that participate in catalysis (130). All Prx enzymes share the same basic catalytic mechanism in which a redox-active cysteine (the peroxidatic cysteine) in the active site is oxidized to a sulfenic acid by the peroxide substrate and then is reduced by a thiol-dependent mechanism during the catalytic cycle. During catalysis, the active site cysteine is occasionally overoxidized to cysteine sulfinic acid (131). In fact, the susceptibility of this active site cysteine to irreversible oxidation accounts for the limited efficiency of peroxiredoxins in eliminating peroxides, which is generally confined to concentrations of $\mathrm{H}_{2} \mathrm{O}_{2}$ below $20 \mu \mathrm{M}$. The thioredoxin/thioredoxin reductase system regenerates the active cysteine site in peroxiredoxins $(132,133)$. Thioredoxins also reduce disulfides in proteins, peptides, and GSSG, as well as directly lower ROS levels through their conserved -Cys-Gly-Pro-Cys- active site sequence $(132,134)$. The active site disulfide in thioredoxin is itself reduced by the selenoprotein thioredoxin reductase and $\mathrm{NAD}(\mathrm{P}) \mathrm{H}(135)$. Thioredoxin also has redox-sensitive signaling functions through stimulation of DNA-binding 
of nuclear factor kappa B (NFkappaB (p50 subunit)), increasing activator protein-1 (AP-1) binding activity (redox factor-1 (Ref-1)), and binding to the MAPKK kinase ASK1 (132). Thioredoxin expression is induced by oxidative stress.

In contrast to the peroxiredoxins, the glutathione peroxidases (GPxs) catalyze the reduction of $\mathrm{H}_{2} \mathrm{O}_{2}$ and organic hydroperoxides to alcohols using $\mathrm{GSH}$ as a reductant (136). In addition, these selenoproteins have a unique GSH-dependent ability to catalyze the reduction of peroxynitrite (137). This class of enzymes includes GPx-1, which is ubiquitously expressed in cytosol and mitochondria of all cells; GPx-3, which is the most abundant extracellular antioxidant enzyme; and GPx-4 or phospholid glutathione peroxidase, which is also widely expressed and reduces membrane phosholipid hydroperoxides. In addition, the glutathione $S$ transferases are another class of glutathione-dependent antioxidant enzymes that can inactivate lipid peroxides, although their importance in the vasculature is less well understood (114, 138).

Heme oxygenase has indirect antioxidant effects through degradation of free heme and the production of $\mathrm{CO}$, as well as biliverdin and bilirubin, which themselves have antioxidant properties (139). There are two isoforms of this enzyme, a constitutive heme oxygenase, HO-2, which is ubiquitously expressed in endothelial cells, and $\mathrm{HO}-1$, which is induced in response to oxidative stress.

\section{NITRIC OXIDE}

\subsection{Role of nitric oxide in the vasculature}

Nitric oxide is an omnipresent signaling molecule with a short half-life that either acts within the source cell or diffuses from the source cell to affect adjacent cells (140). The targets of NO depend on the environment and on the quantity produced (141). Nitric oxide is an uncharged free radical composed of seven electrons from nitrogen and eight electrons from oxygen (142-144).

The local level of NO is determined by the balance between its rate of formation or exogenous production (e.g., cigarette smoke, medication), and its rate of inactivation (145). Nitric oxide is produced by a variety of mammalian cells, including vascular endothelium, neurons, smooth muscle cells, macrophages, neutrophils, platelets, and pulmonary epithelium (146). The physiological actions of NO range from modulating the vascular system (blood flow, inhibition of platelet adherence/aggregation, angiogenesis), to regulating the immune system (cellular immunity by macrophage, neutrophil killing of pathogens, non-specific host defense) and controlling neuronal functions (neurotransmission, synaptic plasticity in the central nervous system, oscillatory behaviour of neuronal networks) (146-147).

Under physiological conditions, NO formation is stimulated by shear forces acting on the vascular endothelium generated by flowing blood or by agonist activation of endothelial receptors (148-149). Based on this stimulation, $\mathrm{Ca}^{2+}$ influx triggers the enzymatic activation of constitutively expressed endothelial membrane-bound NOS (cNOS; eNOS; NOS III).

Bacterial endotoxins and inflammatory cytokines, such as TNF-alpha and interleukins, activate the inducible NOS (iNOS; NOS II), which produces $\mathrm{Ca}^{2+}$-independent $\mathrm{NO}$ at a rate 1,000 -fold greater than that of eNOS (150). In the vasculature, iNOS can be induced in infiltrating macrophages and lymphocytes, endothelial cells, smooth muscle cells, or fibroblasts, whereas eNOS is predominantly produced in endothelial cells. In addition, there is a neural NOS (nNOS; NOS I) that primarily produces $\mathrm{NO}$ as a transmitter in the brain and in the peripheral nervous system, such as in non-adrenergic, non-cholinergic (NANC) autonomic nerves that innervate penile erectile tissue and other specialized tissues in the body to promote vasodilation (151). 


\subsection{Control of nitric oxide levels in vascular tissue}

5.2.1. The bioreactivity of nitric oxide-After formation of NO by eNOS in the vascular endothelium, NO binds to the iron (III) hemes of cytochrome $c$ oxidase in mitochondria, regulates certain transcription factors such as hypoxia-inducible factor-1 (HIF-1), or rapidly diffuses into the blood (143). In the vascular lumen, NO is readily scavenged by erythrocytes in which it reacts with the ferrous iron $\left(\mathrm{Fe}^{2+}\right)$ in the heme moiety of oxyhemoglobin to form met-hemoglobin and nitrate $\left(\mathrm{NO}_{3}^{-}\right)(144,152)$. Nitric oxide also diffuses into the vascular smooth muscle cells adjacent to the endothelium where it modulates the activity of hemecontaining soluble guanylyl cyclase (sGC). This enzyme dephosphorylates guanosine triphosphate (GTP) to produce cyclic guanosine 3',5'-cyclic monophosphate (cGMP), which activates $\mathrm{K}^{+}$channels and inhibits $\mathrm{Ca}^{2+}$ entry into smooth muscle cells by directly inhibiting voltage-gated $\mathrm{Ca}^{2+}$ channels, and activates protein kinases that phosphorylate myosin light chains and phosphorylate sarcoplasmic proteins, leading to the sequestration of $\mathrm{Ca}^{2+}$ in the sarcoplasmic reticulum (153-154). The reduction in cytosolic $\mathrm{Ca}^{2+}$ concentration affects phosphorylation of the regulatory myosin light chains and ultimately promotes smooth muscle cell relaxation (155).

Theoretically, $\mathrm{NO}$ can exist in three closely related redox forms: the free radical $\mathrm{NO}^{\circ} ; \mathrm{NO}^{+}$or nitrosonium, resulting from a one-electron oxidation of $\mathrm{NO}^{\circ}$; and $\mathrm{NO}^{-}$or nitroxyl anion, resulting from a one-electron reduction of $\mathrm{NO}^{*}$. Nitrogen oxide $\left(\mathrm{NO}^{\mathrm{x}}\right)$ species react with oxygen-derived radicals, redox metals, and thiols (Figure 3) (156-157). Nitric oxide can be reduced to nitrous oxide $\left(\mathrm{N}_{2} \mathrm{O}\right)$ or oxidized to nitrite $\left(\mathrm{NO}_{2}^{-}\right)(157)$. Nitrite can react rapidly with oxygen, yielding nitrogen dioxide radical $\left({ }^{\circ} \mathrm{NO}_{2}\right)$, which exists in equilibrium with the potent nitrosating agents dinitrogen trioxide $\left(\mathrm{N}_{2} \mathrm{O}_{3}\right)$ and dinitrogen tetroxide $\left(\mathrm{N}_{2} \mathrm{O}_{4}\right)$; ${ }^{\circ} \mathrm{NO}_{2}$ can either react with unsaturated lipids directly or participate in nitrosation reactions. Nitric oxide does not directly nitrosate organic molecules without a strong oxidizing cofactor to accept an electron, such as transition metals or ${ }^{\circ} \mathrm{NO}_{2}$. Dinitrogen trioxide can nitrosate cysteinyl residues ( $S$-nitrosation), forming $S$-nitrosothiols (RSNO), which are naturally found in cells and plasma (158). Owing to their relative stability, $S$-nitrosothiols are an important form of NO and may serve as a functional storage pool of bioavailable NO (73). In plasma, $S$ nitrosoalbumin is an important $\mathrm{NO}$ adduct that may protect $\mathrm{NO}$ from inactivation in the oxidative extracellular milieu (158).

The dinitrogen species can also nitrosate ( $N$-nitrosation) secondary amines to yield procarcinogenic $N$-nitrosamines (RNNO), and are involved in the formation of nitrotyrosine and $N$-nitrosotryptophan (159-161). These reactive nitrogen compounds can also nitrosatively deaminate deoxynucleosides and deoxynucleotides and promote mutagenic DNA strand breaks (162). Biochemical studies in rat aortas reveal that $N$-nitroso compounds also exist in vascular tissue, but functional data suggest that RSNOs are more active by an order of magnitude than RNNO (163). Additional studies are necessary to understand the biological significance of various RSNO and RNNO species.

At low concentrations, intracellular NO may function as an antioxidant through termination reactions with lipid radicals $\left(\mathrm{L}^{*}, \mathrm{LO}^{*}, \mathrm{LOO}^{\circ}\right)$, resulting in the formation of less reactive secondary nitrogen-containing products (LONO, LOONO) at near diffusion-limited rates $\left(10^{9}\right.$ to $\left.10^{11} \mathrm{M}^{-1} \mathrm{~s}^{-1}\right)$ (142). LOONO can either decompose to caged radicals $\left(\mathrm{LO}^{\circ} \mathrm{NO}_{2}\right)$ with rearrangement of $\mathrm{LO}^{\circ}$ to an epoxide $\left(\mathrm{L}(\mathrm{O}) \mathrm{NO}_{2}\right)$, dissociate and react with additional $\mathrm{NO}$, or hydrolyze to $\mathrm{LOOH}$ and nitrite $\left(\mathrm{NO}_{2}^{-}\right)$(157). Thus, by these chemical actions, $\mathrm{NO}$ suppresses the generation of lipid-derived products that are chemotactic for monocytes, and can thereby be considered antiinflammatory and potentially antiatherosclerotic $(164,165)$.

5.2.2. Nitric oxide signaling properties-Other antiatherosclerotic actions of NO are its antithrombotic antiplatelet effects that contribute to maintaining vascular integrity and blood 
flow $(166,167)$. Produced by the intact endothelium, potent platelet inhibitors include prostacyclin, endothelial surface-bound ecto- $\mathrm{AD}(\mathrm{T})$ Pase (CD39), and NO, all of which affect platelet activation and function in differing, but complementary, ways (168). Nitric oxide diffuses into platelets and, similar to effects on vascular smooth muscle cells, stimulates cGMP production and activates cGMP-dependent protein kinases, resulting in a decrease in intracellular $\mathrm{Ca}^{2+}$ flux (169-171). $\mathrm{Ca}^{2+}$ is also an important second messenger in platelets, and its accumulation leads to the phosphorylation and activation of several $\mathrm{Ca}^{2+}$-dependent enzymes that results in cytoskeletal rearrangement, shape change, release of storage granules, and platelet aggregation (168). Furthermore, cGMP, in part through the downregulation of PKC, regulates the desensitization of the thromboxane $\mathrm{A}_{2}\left(\mathrm{TXA}_{2}\right)$ receptor, a potent stimulator of platelet aggregation and vasoconstriction. By attenuating conformational changes in glycoprotein (GP) IIb/IIIa, cGMP controls the number and affinity of fibrinogen binding sites on the platelet surface and prevents the surface expression of the alpha-granule protein Pselectin, a mediator of platelet adhesion $(172,173)$. Nitric oxide may also inhibit platelet activation by cGMP-independent mechanisms, such as its effects on non-specific cation channels (169).

In addition, through cGMP-dependent and -independent mechanisms, NO participates in the regulation of vascular smooth muscle cell migration, growth, and proliferation. Calcium promotes vascular smooth muscle cell proliferation, and, as in other cell types, NO decreases intracellular $\mathrm{Ca}^{2+}$ flux mediated by cGMP, promoting its antiproliferative action (174). In addition to regulating platelet and vascular smooth muscle cell function, NO has antiinflammatory effects by controlling leukocyte responses through inhibition of cytokinemediated cell adhesion molecule expression $(175,176)$.

\section{ATHEROTHROMBOSIS}

\subsection{Impaired vascular nitric oxide bioavailability and oxidative stress}

A dominant mechanisms of impaired vascular NO bioavailability relates to its oxidative inactivation by $\mathrm{O}_{2}^{-\bullet}$. A central feature of impaired endothelial function is the presence of ROS manifested by ox-LDL in hypercholesterolemia, glycoxidation products in hyperglycemia, redox-active compounds in tobacco smoke, and lipid peroxides in hyperhomocysteinemia owing to the homocysteine-dependent suppression of GPx-1 (177-179). Oxidized lipids can also be generated by metal-dependent Fenton oxidation; enzyme-catalyzed oxidation by lipoxygenase (LOX) (180-182) or reaction with $\mathrm{HOCl}$ generated by myeloperoxidase; celldependent oxidation via a diversity of $\mathrm{O}_{2}^{-\bullet}$ and $\mathrm{H}_{2} \mathrm{O}_{2}$-generating oxidases; and oxidation by NO-derived reactive nitrogen species such as ${ }^{\circ} \mathrm{NO}_{2}$, nitryl chloride $\left(\mathrm{NO}_{2} \mathrm{Cl}\right)$, and peroxynitrite (183-185).

Oxidative stress, particulary ox-LDL, plays a key role at several steps of atherogenesis, according to the 'oxidative-modification hypothesis of atherosclerosis' (186-188). Initially localized in the vascular subendothelial space, LDL is oxidatively modified by endothelial cells, vascular smooth muscle cells, and monocytes. Macrophages within the vessel wall internalize ox-LDL via scavenger receptors, and develop into lipid-rich 'foam cells' (189-191). Evidence that LDL oxidation occurs in vivo is supported by the reaction of ox-LDL antibodies with atherosclerotic lesions $(188,192)$.

\subsection{Inflammation}

Oxidation of LDL and increased oxidative stress stimulates proinflammatory signals by transcription of genes sensitive to changes in cellular oxidant production, as well as by modulation of cell-signaling events (193). Following exposure to cytokines, such as interleukin-1beta or TNF-alpha, endothelial cells are activated to express vascular cell adhesion 
molecule-1, intercellular adhesion molecule-1, and E-selectin, all of which promote leukocyte binding. Moreover, the activated endothelium produces chemoattractants, such as interleukin- 8 and monocyte chemotactic protein-1, that facilitate monocyte recruitment and adhesion to the vessel wall and initiate early stages of atherosclerosis $(194,195)$. Superoxide anion and other ROS also promote transcription-dependent inflammatory processes, in part, controlled by the redox-sensitive transcriptional regulatory protein NFkappaB that is normally downregulated by NO under physiological conditions (196). NFkappaB is also important in proliferative signals involved in vascular smooth muscle cell growth, vascular remodeling, and atherogenesis. Evidence for the involvement of ROS in NFkappaB acitivation is provided by studies demonstrating its downregulation by antioxidants, such as catalase, SOD, and $\mathrm{N}$ acetylcysteine (84).

The role of ROS in inflammation is supported by the fact that NAD(P)H oxidase-dependent $\mathrm{O}_{2}{ }^{-}$production is found in shoulder regions of the atherosclerotic plaque (34). In this region, ROS also correlate with an increase in the proteolytic activity of matrix metalloproteinases $(197,198)$. In patients with acute coronary syndrome, atherectomy specimens show increased levels of ROS compared to those from patients with stable angina, supporting a mechanistic role for ROS in plaque composition and behavior (199). In hypercholesteremic rabbits, $N$ acetylcysteine, a potent antioxidant, decreases matrix metalloproteinases- 9 expression and activation, suggesting antioxidant therapy may be an effective means to stabilize plaques (197). In the same animal model, $\mathrm{O}_{2}^{-\bullet}$ is increased in aortic tissue, and treatment with SOD attenuates impairment of endothelium-dependent relaxation (5,200-201). Similarly, increased $\mathrm{O}_{2}{ }^{-\bullet}$ production is found in blood vessels from human subjects with coronary artery disease, hypercholesterolemia, and diabetes mellitus (202).

\subsection{Peroxynitrite formation}

In the atherosclerotic plaque, levels of $\mathrm{NO}$ can be elevated, generated typically after induction of iNOS (203). Exogenous cigarette smoke also yields high levels of NO that contribute to the formation of more potent secondary oxidants from $\mathrm{O}_{2}{ }^{-\bullet}$, most notably peroxynitrite (204). The formation of peroxynitrite from $\mathrm{O}_{2}^{-\bullet}$ and $\mathrm{NO}$ occurs at the diffusion limit with a rate $(k=\sim 6.7$ $\left.\times 10^{9} \mathrm{M}^{-1} \cdot \mathrm{s}^{-1}\right)(120,205)$ that is faster than that of the SOD reaction or of NO with heme compounds (206). Thus, $\mathrm{NO}$ can be considered a scavenger of $\mathrm{O}_{2}^{-\bullet}$, even to the extent of acting as an antioxidant; in fact, $\mathrm{NO}$ is the only biological molecule that can kinetically outcompete SOD for $\mathrm{O}_{2}^{-\bullet}(85,207-209)$. In mitochondria, NO binds to cytochrome oxidase, inhibits mitochondrial respiration, increases $\mathrm{O}_{2} \cdot$ production, and potentially augments peroxynitrite formation $(210,211)$. Significantly, peroxynitrite inactivates Mn-SOD, thereby increasing the flux of $\mathrm{O}_{2}-\bullet$ available to react with $\mathrm{NO}$ and establishing an autocatalytic spiral of increasing mitochondrial peroxynitrite formation $(212,213)$.

At physiological $\mathrm{pH}$, peroxynitrite exists primarily as peroxynitrite anion $\left(\mathrm{ONOO}^{-}\right)$, a stable base (pKa of $\sim 6.8$ at $37^{\circ} \mathrm{C}$ ) in cis-conformation. Its conjugate, peroxynitrous acid $(\mathrm{ONOOH})$, comprises approximately $20 \%$ of total peroxynitrite at physiological $\mathrm{pH}$. The transperoxynitrous acid is a strong oxidant and highly reactive, and, theoretically, may form an excited state that reacts like hydroxyl radical. Peroxynitrous acid is also capable of rearranging to nitrate $(214,215)$. Peroxynitrite, unlike its precursor NO, is probably not an intercellular messenger molecule, although by modifying target proteins involved in signal transduction, peroxynitrite may have profound effects on cell signaling (216-217). Homolytic cleavage of peroxynitrite can produce ${ }^{\circ} \mathrm{OH}$ and ${ }^{\circ} \mathrm{NO}_{2},(205)$ which react together to form nitrate, to reform HOONO (cage return), or diffuse apart, leaving free radicals that can cause other oxidative events.

Peroxynitrite formation has two important biological consequences: loss of bioactive NO and direct cytotoxic effects (Figure 4). Peroxynitrite and its conjugate acid can oxidize a variety of 
biomolecules, including free thiols, such as cysteine, glutathione, or cysteinyl residues in protein; lipids; deoxyribose; guanine bases; methionine; and phenols $(214,215,218-222)$. The consequences of these oxidations are protein modification, inhibition of mitochondrial respiration and of other enzymes, and lipid peroxidation (223). Peroxynitrite can also inactivate various ion channels, inhibit membrane $\mathrm{Na}^{+} / \mathrm{K}^{+}$ATP-ase activity, and inactivate glyceraldehyde-3-phosphate dehydrogenase (224-226). The reaction with DNA to form 8hydroxydeoxyguanosine, single DNA strand breaks, and the activation of the DNA repair nuclear enzyme poly-ADP ribosyl synthetase with depletion of cellular NADH are also important cytotoxic effects of peroxynitrite $(221,227-229)$.

In the intracellular compartment, peroxynitrite may preferentially oxidize free thiols (RSH) such as glutathione in a second order reaction, particularly with the anion form $\left(\mathrm{RS}^{-}\right)$, resulting in the formation of an intermediate sulfenic acid (RSOH), that then reacts with another thiol, forming disulfides (RSSR) (214,230-231). Thiols may also be oxidized by the radicals formed from peroxynitrite, generating thiyl radicals (RS*); thiyl radicals may react with oxygen and promote oxidative stress or react with $\mathrm{NO}$ to form RSNO and promote transnitrosation of protein thiols (Protein-SNO). Peroxynitrite itself is not a direct nitrosating agent, but is involved in the nitrosation of thiols to yield RSNO or organic nitrates $\left(\mathrm{RONO}_{2}\right)(232-236)$. Peroxynitrite catalysis can be promoted by the presence of transition metals, SOD, or myeloperoxidase to produce hydroxyl anion $\left(\mathrm{OH}^{-}\right)$plus nitronium cation $\left(\mathrm{NO}_{2}{ }^{+}\right)$(one-electron oxidation); $\mathrm{NO}_{2}{ }^{+}$ then reacts with phenolics to produce nitrophenols (237-238). The nitration of protein tyrosinyl residues to yield 3-nitrotyrosine is a stable byproduct left by the short-lived peroxynitrite in vivo (234). Tyrosine does not react directly with peroxynitrite; rather, tyrosine nitration occurs through a radical mechanisms in which a hydrogen atom is first abstracted from the phenol ring to form a tyrosyl radical that quickly combines with ${ }^{\circ} \mathrm{NO}_{2}$ to produce 3-nitrotyrosine. This reaction competes favorably with a secondary reaction in which tyrosyl combines with another tyrosyl radical to form dityrosine $(239,240)$. Immunodetectable 3-nitrotyrosine has been demonstrated in fatty streaks of coronary arteries of young autopsy subjects and in foam cells, vascular endothelium, and the neointima of advanced atherosclerosic lesions in older patients (241). Tyrosine nitration can inactivate enzymes (e.g., MnSOD) and disrupt tyrosine kinase signaling pathways by blocking tyrosine phosphorylation $(212,242-243)$.

The plasma thiol concentration is approximately one-tenth that of the cytosol; therefore, extracellular peroxynitrite will tend to react with non-thiol targets, such as LDL, to generate vasoconstrictive isoprostanes and reactive aldehydes (244). Peroxynitrite is unique as a lipid oxidant, producing lipid peroxyl radicals, and mediates peroxidation of diverse classes of lipids (e.g., purified fatty acids, neutral lipids, phospholipids, lipophilic antioxidants, and LDL lipids) forming conjugated dienes, malondialdehyde, lipid peroxides, lipid hydroxides, $\mathrm{F}_{2}-$ isoprostanes, and oxysterol products $(219,245-247)$. Peroxynitrite can also react with extracellular carbohydrates.

Cellular damage by peroxynitrite is augmented by its reaction with carbon dioxide radical $\left(\mathrm{CO}_{2}{ }^{\circ}\right)$ and formation of highly reactive free radicals. The concentration of carbon dioxide $\left(\mathrm{CO}_{2}\right)$ in the plasma is high $(\sim 1.3 \mathrm{mM})$, which is maintained by equilibrium with $\mathrm{HCO}_{3}{ }^{-}$ $(\sim 25 \mathrm{mM})$. Consequently, in plasma the reaction rate of peroxynitrite with $\mathrm{CO}_{2}$ will be $\sim 60-$ fold greater than that with thiols (248-249). The result of this reaction is the formation of nitrosoperoxycarbonate anion $\left(\mathrm{ONO}_{2} \mathrm{CO}_{2}^{-}\right)\left(\mathrm{k}_{2}=\sim 5 \times 10^{4} \mathrm{M}^{-1} \bullet \mathrm{s}^{-1}\right.$ at $\left.37^{\circ} \mathrm{C}\right)$, which subsequently rearranges to form nitrocarbonate (248). Theoretically, nitrocarbonate can undergo hydrolysis to form carbonate radical $\left(\mathrm{CO}_{3}{ }^{-}\right)$and ${ }^{\circ} \mathrm{NO}_{2}$ as a pair of caged radicals, which $\sim 66 \%$ of the time recombine to $\mathrm{CO}_{2}$ plus $\mathrm{NO}_{3}{ }^{-}$and $\sim 33 \%$ of the time escape the solvent cage; it is these radicals that are believed to cause peroxynitrite-related cellular NO damage (250). Nitrocarbonate can also oxidize substrates via one- and two-electron transfers, and may 
also nitrosate substrates. In vitro studies have shown that $\mathrm{CO}_{2}$ enhances tyrosine nitration by peroxynitrite (251).

Several approaches can be used to prevent or repair peroxynitrite-induced cellular injury. One can decrease the production of NO with NOS inhibitors, or decrease $\mathrm{O}_{2}{ }^{-\bullet}$ formation by increasing SOD levels or by inhibiting xanthine and NAD $(\mathrm{P}) \mathrm{H}$ oxidases. Other approaches depend on enhancing the reduction of peroxynitrite to $\mathrm{NO}_{2}{ }^{-}$or rearrangement to $\mathrm{NO}_{3}{ }^{-}$by using organoselenium compounds, metalloporphyrin derivates, and peroxidases (252-255). Glutathione peroxidise-1, the most abundant selenocysteine-containing GPx, may play a role in the reduction of peroxynitrite (137). The relevance of this enzyme in protecting against oxidative stress has been demonstrated in cell culture, murine models of GPx-1 deficiency, and human subjects (179,256-257). Compared to wild-type mice, heterozygous and homozygous GPx-1-deficient mice show an increase in plasma and aortic levels of isoprostane $\mathrm{iPF}_{2 \mathrm{alpha}}-\mathrm{III}$, a marker of oxidant stress. These GPx-1 deficient mice also have endothelial dysfunction and increased immunodetectable 3-nitrotyrosine in the aorta.

\subsection{Platelet activation and thrombus formation}

In response to blood vessel injury, platelets accumulate at the site, recruit other platelets, promote clotting, and form a hemostatic plug to prevent hemorrhage; in the course of their activation, platelets are a rich source of ROS, including $\mathrm{O}_{2}^{-\bullet}, \mathrm{H}_{2} \mathrm{O}_{2}$ and LOOH. In addition to promoting endothelial dysfunction and atherogenesis, NO insufficiency combined with ROS accumulation predisposes to a platelet-dependent prothrombotic disorder. Reduction of NO and induction of $\mathrm{O}_{2}^{-}$formation cause an increase in intracellular $\mathrm{Ca}^{2+}$ levels in platelets. Increased $\mathrm{Ca}^{2+}$ levels activate cytoskeletal rearrangement, alpha- and dense-granule release, and overall platelet activation. Impaired $\mathrm{NO}$ bioavailability causes secretion of $\mathrm{TXA}_{2}$ from the platelets, which consequently activates additional platelets in the microenvironment of the platelet plug. For hemostatic plug formation, platelets interact with one another by forming crosslinks through cell surface integrin receptors, thereby leading to aggregation. Fibrinogen, a bivalent molecule, augments aggregation by linking the GPIIb/IIIa receptors between activated platelets (258). Nitric oxide released from activated platelets regulates the recruitment of additional platelets to the growing thrombus (259). Platelet adherence to the endothelium requires the expression of P-selectin, a cell-surface protein found in endothelial cells and alphagranules of platelets, which is normally downregulated by $\mathrm{NO}(173,260)$. In a study of platelet function from human subjects with a thrombotic disorder, NO failed to inhibit platelet Pselectin expression and platelet aggregation. The unresponsiveness of these platelets to NO was found to be associated with decreased GPx-3 activity (261). Glutathione peroxidise- 3 is the only isoform in the GPx family that is found in the extracellular space, and is responsible for the majority of the peroxidase activity in plasmas (262). Addition of exogeneous GPx led to the restoration of NO's inhibitory effect on platelets in these patients' plasmas. Thus, GPx-3 maintains the bioavailability of NO by preventing the accumulation of ROS that are generated during the activation of the platelet second messenger cascade and may regulate subsequent conformational changes in cytoskeletal structure. In fact, $\mathrm{H}_{2} \mathrm{O}_{2}$ has been found to mediate changes in intracellular $\mathrm{Ca}^{2+}$ levels and affect $\mathrm{Ca}^{2+}$-related mechanisms through sulfhydryl oxidation-dependent and -independent mechanisms within platelets (263). The modulation of intracellular $\mathrm{Ca}^{2+}$ levels by $\mathrm{H}_{2} \mathrm{O}_{2}$ occurs through stimulatory $\mathrm{Ca}^{2+}$ release from the dense tubular system and mitochondria within platelets, concurrent with inhibition of $\mathrm{Ca}^{2+}$ reuptake into the dense tubular system mediated by sarcoplasmatic reticulum $\mathrm{Ca}^{2+}$ ATPase $(264,265)$. The consequences of platelet activation and thrombus formation, as well as atherosclerotic plaque disruption (rupture or erosion), are key features of atherothrombosis. 


\section{CONCLUSION}

Cardiovascular risk factors promotes the production of ROS, and an imbalance between endogenous oxidants and antioxidants results in oxidative stress, a condition that contributes to impaired $\mathrm{NO}$ bioavailability and vascular dysfunction. The generation of $\mathrm{O}_{2}{ }^{-\bullet}$ by $\mathrm{NAD}(\mathrm{P})$ $\mathrm{H}$ oxidase in vascular smooth muscle cells and by NAD(P)H oxidase or uncoupled eNOS in activated or dysfunctional endothelial cells can promote the production of peroxynitrite from the diffusion-controlled reaction between $\mathrm{O}_{2}{ }^{-}$and NO. Oxidative stress characterized by lipid and protein oxidation in the vascular wall is considered an early event in atherogenesis. The oxidative respiratory burst from leukocytes that enter the vessel wall in the early inflammatory response to vascular injury and the production of oxidized arachidonate derivatives by activated platelets in the early thrombotic response to vascular injury represent key mechanistic determinants of atherothrombosis that reflect ROS flux.

\section{ACKNOWLEDGMENTS}

This work was supported by NIH grants HL 58976, HL 61795, HV 28178, and HL 81587 from the National Heart, Lung, and Blood Institute (NHLBI), and by a Deutsche Forschungsgemeinschaft grant, LU 1452/1-1. The authors wish to thank Stephanie Tribuna for expert technical assistance, and Jutta Benirschke for graphics work.

Disclaimer: The project described was supported by Award numbers HL 61795, HL 58976, N01 HV 28178, and P01 HL 81587 from the National Heart, Lung, and Blood Institute. The content is solely the responsibility of the authors and does not necessarily represent the official views of the National Heart, Lung, and Blood Institute or the National Institutes of Health.

\section{Abbreviations}

AP-1, Activator protein-1

ACE, angiotensin converting enzyme

ADMA, asymmetric dimethyl arginine

$\mathrm{CO}_{2}{ }^{\circ}$, carbon dioxide radical

$\mathrm{CO}_{2}$, carbon dioxide

$\mathrm{CO}_{3}{ }^{-}$, carbonate radical

cGMP, cyclic guanosine 3',5'-cyclic monophosphate

FAD, flavin adenine nucleotide

$\mathrm{Fe}^{2+}$, ferron iron

GSH, glutathione

GSSG, glutathione disulfide

GPx, glutathione peroxidase

GP, glycoprotein

$\mathrm{HO}$, heme oxygenase isoform

$\mathrm{H}_{2} \mathrm{O}_{2}$, hydrogen peroxide

$\mathrm{OH}^{-}$, hydroxyl anion

$\cdot \mathrm{OH}$, hydroxyl radical

$\mathrm{HOCl}$, hypochlorous acid

HIF-1, hypoxia-inducible factor-1

LOX, lipooxygenase

LDL, low density lipoprotein

$\mathrm{O}_{2}$, molecular oxygen

$\mathrm{NAD}(\mathrm{P}) \mathrm{H}$, nicotinamide adenine dinucleotide (phosphate) oxidase

$\mathrm{NO}_{3}{ }^{-}$, nitrate

$\mathrm{NO}_{2}{ }^{-}$, nitrite

NO, nitric oxide

NOS, nitric oxide synthase 
$\mathrm{NO}^{2+}$, nitronium cation

$\mathrm{ONO}_{2} \mathrm{CO}_{2}{ }^{-}$, nitrosoperoxy carbonate

$\mathrm{NO}_{2} \mathrm{Cl}$, nitryl chloride

NANC, non-adrenergic, non-cholinergic

Nox, non-phagocytic NAD(P)H oxidase

$\mathrm{N}_{2}$, nitrogen

NFkappaB, nuclear factor kappaB

ROS, reactive oxygen species

RNS, reactive nitrogen species

$\mathrm{RSOH}$, sulfenic acid

$\mathrm{O}_{2}^{-\bullet}$, superoxide anion

SOD, superoxide dismutase

$\mathrm{ONOO}^{-}$, peroxynitrite anion

ONOOH, peroxynitrous acid

$\mathrm{PKC}$, protein kinase $\mathrm{C}$

sGC, soluble guanylyl cyclase

$\mathrm{BH}_{4}$, tetrahydrobiopterin

TNF-alpha, tumor necrosis factor-alpha

$\mathrm{RS}^{\bullet}$, thiyl radical

$\mathrm{TXA}_{2}$, thromboxane $\mathrm{A}_{2}$

$\mathrm{XR}$, xanthine dehydrogenase

$\mathrm{XO}$, xanthine oxidase

XOR, xanthine oxidoreductase

$\mathrm{H}_{2} \mathrm{O}$, water

\section{REFERENCES}

1. Kojda G, Harrison D. Interactions between NO and reactive oxygen species: pathophysiological importance in atherosclerosis, hypertension, diabetes and heart failure. Cardiovasc Res 1999;43:562571. [PubMed: 10690328]

2. Mohazzab KM, Kaminski PM, Wolin MS. NADH oxidoreductase is a major source of superoxide anion in bovine coronary artery endothelium. Am J Physiol 1994;266:H2568-H2572. [PubMed: 8024019]

3. Meneshian A, Bulkley GB. The physiology of endothelial xanthine oxidase: from urate catabolism to reperfusion injury to inflammatory signal transduction. Microcirculation 2002;9:161-175. [PubMed: 12080414]

4. Rajagopalan S, Kurz S, Munzel T, Tarpey M, Freeman BA, Griendling KK, Harrison DG. Angiotensin II-mediated hypertension in the rat increases vascular superoxide production via membrane NADH/ NADPH oxidase activation. Contribution to alterations of vasomotor tone. J Clin Invest 1996;97:19161923. [PubMed: 8621776]

5. White CR, Brock TA, Chang LY, Crapo J, Briscoe P, Ku D, Bradley WA, Gianturco SH, Gore J, Freeman BA, et al. Superoxide and peroxynitrite in atherosclerosis. Proc Natl Acad Sci U S A 1994;91:1044-1048. [PubMed: 8302829]

6. Moncada S, Martin JF. Evolution of nitric oxide. Lancet 1993;341:1511. [PubMed: 8099386]

7. Kelm M, Schrader J. Control of coronary vascular tone by nitric oxide. Circ Res 1990;66:1561-1575. [PubMed: 2160870]

8. Vane JR, Anggard EE, Botting RM. Regulatory functions of the vascular endothelium. N Engl J Med 1990;323:27-36. [PubMed: 2113184]

9. Heitzer T, Schlinzig T, Krohn K, Meinertz T, Munzel T. Endothelial dysfunction, oxidative stress, and risk of cardiovascular events in patients with coronary artery disease. Circulation 2001;104:26732678. [PubMed: 11723017] 
10. Schachinger V, Britten MB, Zeiher AM. Prognostic impact of coronary vasodilator dysfunction on adverse long-term outcome of coronary heart disease. Circulation 2000;101:1899-1906. [PubMed: 10779454]

11. Cai H, Harrison DG. Endothelial dysfunction in cardiovascular diseases: the role of oxidant stress. Circ Res 2000;87:840-844. [PubMed: 11073878]

12. Jones SA, O'Donnell VB, Wood JD, Broughton JP, Hughes EJ, Jones OT. Expression of phagocyte NADPH oxidase components in human endothelial cells. Am J Physiol 1996;271:H1626-H1634. [PubMed: 8897960]

13. Griendling KK, Minieri CA, Ollerenshaw JD, Alexander RW. Angiotensin II stimulates NADH and NADPH oxidase activity in cultured vascular smooth muscle cells. Circ Res 1994;74:1141-1148. [PubMed: 8187280]

14. Sorescu D, Somers MJ, Lassegue B, Grant S, Harrison DG, Griendling KK. Electron spin resonance characterization of the NAD $(\mathrm{P}) \mathrm{H}$ oxidase in vascular smooth muscle cells. Free Radic Biol Med 2001;30:603-612. [PubMed: 11295358]

15. Pagano PJ, Clark JK, Cifuentes-Pagano ME, Clark SM, Callis GM, Quinn MT. Localization of a constitutively active, phagocyte-like NADPH oxidase in rabbit aortic adventitia: enhancement by angiotensin II. Proc Natl Acad Sci U S A 1997;94:14483-14488. [PubMed: 9405639]

16. Pagano PJ, Chanock SJ, Siwik DA, Colucci WS, Clark JK. Angiotensin II induces p67phox mRNA expression and NADPH oxidase superoxide generation in rabbit aortic adventitial fibroblasts. Hypertension 1998;32:331-337. [PubMed: 9719063]

17. Griendling KK, Sorescu D, Ushio-Fukai M. NAD(P)H oxidase: role in cardiovascular biology and disease. Circ Res 2000;86:494-501. [PubMed: 10720409]

18. Babior BM. NADPH oxidase: an update. Blood 1999;93:1464-1476. [PubMed: 10029572]

19. Duerrschmidt N, Wippich N, Goettsch W, Broemme HJ, Morawietz H. Endothelin-1 induces NAD (P)H oxidase in human endothelial cells. Biochem Biophys Res Commun 2000;269:713-717. [PubMed: 10720482]

20. Holland JA, Pritchard KA, Pappolla MA, Wolin MS, Rogers NJ, Stemerman MB. Bradykinin induces superoxide anion release from human endothelial cells. J Cell Physiol 1990;143:21-25. [PubMed: 2156873]

21. Ushio-Fukai M, Tang Y, Fukai T, Dikalov SI, Ma Y, Fujimoto M, Quinn MT, Pagano PJ, Johnson $\mathrm{C}$, Alexander RW. Novel role of gp91(phox)-containing NAD(P)H oxidase in vascular endothelial growth factor-induced signaling and angiogenesis. Circ Res 2002;91:1160-1167. [PubMed: 12480817]

22. Matsubara T, Ziff M. Increased superoxide anion release from human endothelial cells in response to cytokines. J Immunol 1986;137:3295-3298. [PubMed: 3021851]

23. Frey RS, Rahman A, Kefer JC, Minshall RD, Malik AB. PKCzeta regulates TNF-alpha-induced activation of NADPH oxidase in endothelial cells. Circ Res 2002;90:1012-1019. [PubMed: 12016268]

24. Inoguchi T, Li P, Umeda F, Yu HY, Kakimoto M, Imamura M, Aoki T, Etoh T, Hashimoto T, Naruse M, Sano H, Utsumi H, Nawata $\mathrm{H}$. High glucose level and free fatty acid stimulate reactive oxygen species production through protein kinase $\mathrm{C}$--dependent activation of $\mathrm{NAD}(\mathrm{P}) \mathrm{H}$ oxidase in cultured vascular cells. Diabetes 2000;49:1939-1945. [PubMed: 11078463]

25. Hwang J, Ing MH, Salazar A, Lassegue B, Griendling K, Navab M, Sevanian A, Hsiai TK. Pulsatile versus oscillatory shear stress regulates NADPH oxidase subunit expression: implication for native LDL oxidation. Circ Res 2003;93:1225-1232. [PubMed: 14593003]

26. Lopes NH, Vasudevan SS, Gregg D, Selvakumar B, Pagano PJ, Kovacic H, Goldschmidt-Clermont PJ. Rac-dependent monocyte chemoattractant protein-1 production is induced by nutrient deprivation. Circ Res 2002;91:798-805. [PubMed: 12411394]

27. Kim KS, Takeda K, Sethi R, Pracyk JB, Tanaka K, Zhou YF, Yu ZX, Ferrans VJ, Bruder JT, Kovesdi I, Irani K, Goldschmidt-Clermont P, Finkel T. Protection from reoxygenation injury by inhibition of rac1. J Clin Invest 1998;101:1821-1826. [PubMed: 9576744]

28. Schinetti ML, Sbarbati R, Scarlattini M. Superoxide production by human umbilical vein endothelial cells in an anoxia-reoxygenation model. Cardiovasc Res 1989;23:76-80. [PubMed: 2550129]

29. Harrison DG. Endothelial function and oxidant stress. Clin Cardiol 1997;20:II-11-17. 
30. Galle J, Heinloth A, Wanner C, Heermeier K. Dual effect of oxidized LDL on cell cycle in human endothelial cells through oxidative stress. Kidney Int Suppl 2001;78:S120-S123. [PubMed: 11168996]

31. Lassegue B, Sorescu D, Szocs K, Yin Q, Akers M, Zhang Y, Grant SL, Lambeth JD, Griendling KK. Novel gp91(phox) homologues in vascular smooth muscle cells: nox1 mediates angiotensin IIinduced superoxide formation and redox-sensitive signaling pathways. Circ Res 2001;88:888-894. [PubMed: 11348997]

32. Banfi B, Molnar G, Maturana A, Steger K, Hegedus B, Demaurex N, Krause KH. A Ca(2+)-activated NADPH oxidase in testis, spleen, and lymph nodes. J Biol Chem 2001;276:37594-37601. [PubMed: 11483596]

33. Gorlach A, Brandes RP, Nguyen K, Amidi M, Dehghani F, Busse R. A gp91phox containing NADPH oxidase selectively expressed in endothelial cells is a major source of oxygen radical generation in the arterial wall. Circ Res 2000;87:26-32. [PubMed: 10884368]

34. Sorescu D, Weiss D, Lassegue B, Clempus RE, Szocs K, Sorescu GP, Valppu L, Quinn MT, Lambeth JD, Vega JD, Taylor WR, Griendling KK. Superoxide production and expression of nox family proteins in human atherosclerosis. Circulation 2002;105:1429-1435. [PubMed: 11914250]

35. Touyz RM, Chen X, Tabet F, Yao G, He G, Quinn MT, Pagano PJ, Schiffrin EL. Expression of a functionally active gp91phox-containing neutrophil-type NAD(P)H oxidase in smooth muscle cells from human resistance arteries: regulation by angiotensin II. Circ Res 2002;90:1205-1213. [PubMed: 12065324]

36. Rey FE, Li XC, Carretero OA, Garvin JL, Pagano PJ. Perivascular superoxide anion contributes to impairment of endothelium-dependent relaxation: role of gp91(phox). Circulation 2002;106:24972502. [PubMed: 12417549]

37. Granger DN. Role of xanthine oxidase and granulocytes in ischemia-reperfusion injury. Am J Physiol 1988;255:H1269-H1275. [PubMed: 3059826]

38. Cardillo C, Kilcoyne CM, Cannon RO 3rd, Quyyumi AA, Panza JA. Xanthine oxidase inhibition with oxypurinol improves endothelial vasodilator function in hypercholesterolemic but not in hypertensive patients. Hypertension 1997;30:57-63. [PubMed: 9231821]

39. Bouloumie A, Bauersachs J, Linz W, Scholkens BA, Wiemer G, Fleming I, Busse R. Endothelial dysfunction coincides with an enhanced nitric oxide synthase expression and superoxide anion production. Hypertension 1997;30:934-941. [PubMed: 9336396]

40. Marletta MA. Nitric oxide synthase structure and mechanism. J Biol Chem 1993;268:12231-12234. [PubMed: 7685338]

41. Olken NM, Marletta MA. NG-methyl-L-arginine functions as an alternate substrate and mechanismbased inhibitor of nitric oxide synthase. Biochemistry 1993;32:9677-9685. [PubMed: 7690590]

42. Cosentino F, Katusic ZS. Tetrahydrobiopterin and dysfunction of endothelial nitric oxide synthase in coronary arteries. Circulation 1995;91:139-144. [PubMed: 7528647]

43. Laursen JB, Somers M, Kurz S, McCann L, Warnholtz A, Freeman BA, Tarpey M, Fukai T, Harrison DG. Endothelial regulation of vasomotion in apoE-deficient mice: implications for interactions between peroxynitrite and tetrahydrobiopterin. Circulation 2001;103:1282-1288. [PubMed: 11238274]

44. Ueda S, Matsuoka H, Miyazaki H, Usui M, Okuda S, Imaizumi T. Tetrahydrobiopterin restores endothelial function in long-term smokers. J Am Coll Cardiol 2000;35:71-75. [PubMed: 10636262]

45. Higashi Y, Sasaki S, Nakagawa K, Fukuda Y, Matsuura H, Oshima T, Chayama K.

Tetrahydrobiopterin enhances forearm vascular response to acetylcholine in both normotensive and hypertensive individuals. Am J Hypertens 2002;15:326-332. [PubMed: 11991218]

46. Stroes E, Kastelein J, Cosentino F, Erkelens W, Wever R, Koomans H, Luscher T, Rabelink T. Tetrahydrobiopterin restores endothelial function in hypercholesterolemia. J Clin Invest 1997;99:4146. [PubMed: 9011574]

47. Verbeuren TJ, Jordaens FH, Zonnekeyn LL, Van Hove CE, Coene MC, Herman AG. Effect of hypercholesterolemia on vascular reactivity in the rabbit. I. Endothelium-dependent and endothelium-independent contractions and relaxations in isolated arteries of control and hypercholesterolemic rabbits. Circ Res 1986;58:552-564. [PubMed: 3486053] 
48. Vita JA, Treasure CB, Nabel EG, McLenachan JM, Fish RD, Yeung AC, Vekshtein VI, Selwyn AP, Ganz P. Coronary vasomotor response to acetylcholine relates to risk factors for coronary artery disease. Circulation 1990;81:491-497. [PubMed: 2105174]

49. Casino PR, Kilcoyne CM, Quyyumi AA, Hoeg JM, Panza JA. The role of nitric oxide in endotheliumdependent vasodilation of hypercholesterolemic patients. Circulation 1993;88:2541-2547. [PubMed: 8252665]

50. Dhawan V, Handu SS, Nain CK, Ganguly NK. Chronic L-arginine supplementation improves endothelial cell vasoactive functions in hypercholesterolemic and atherosclerotic monkeys. Mol Cell Biochem 2005;269:1-11. [PubMed: 15786711]

51. Cooke JP, Singer AH, Tsao P, Zera P, Rowan RA, Billingham ME. Antiatherogenic effects of Larginine in the hypercholesterolemic rabbit. J Clin Invest 1992;90:1168-1172. [PubMed: 1522225]

52. Wennmalm A, Edlund A, Granstrom EF, Wiklund O. Acute supplementation with the nitric oxide precursor L-arginine does not improve cardiovascular performance in patients with hypercholesterolemia. Atherosclerosis 1995;118:223-231. [PubMed: 8770316]

53. Bode-Boger SM, Scalera F, Ignarro LJ. The 1-arginine paradox: Importance of the 1-arginine/ asymmetrical dimethylarginine ratio. Pharmacol Ther 2007;114:295-306. [PubMed: 17482266]

54. Zou MH, Shi C, Cohen RA. Oxidation of the zinc-thiolate complex and uncoupling of endothelial nitric oxide synthase by peroxynitrite. J Clin Invest 2002;109:817-826. [PubMed: 11901190]

55. Vallance P, Leone A, Calver A, Collier J, Moncada S. Endogenous dimethylarginine as an inhibitor of nitric oxide synthesis. J Cardiovasc Pharmacol 1992;20(Suppl 12):S60-S62. [PubMed: 1282988]

56. Boger RH, Vallance P, Cooke JP. Asymmetric dimethylarginine (ADMA): a key regulator of nitric oxide synthase. Atheroscler Suppl 2003;4:1-3. [PubMed: 14664896]

57. Boger RH, Bode-Boger SM, Szuba A, Tsao PS, Chan JR, Tangphao O, Blaschke TF, Cooke JP. Asymmetric dimethylarginine (ADMA): a novel risk factor for endothelial dysfunction: its role in hypercholesterolemia. Circulation 1998;98:1842-1847. [PubMed: 9799202]

58. Schnabel R, Blankenberg S, Lubos E, Lackner KJ, Rupprecht HJ, Espinola-Klein C, Jachmann N, Post F, Peetz D, Bickel C, Cambien F, Tiret L, Munzel T. Asymmetric dimethylarginine and the risk of cardiovascular events and death in patients with coronary artery disease: results from the AtheroGene Study. Circ Res 2005;97:e53-E59. [PubMed: 16100045]

59. Fleming I, Michaelis UR, Bredenkotter D, Fisslthaler B, Dehghani F, Brandes RP, Busse R. Endothelium-derived hyperpolarizing factor synthase (Cytochrome P450 2C9) is a functionally significant source of reactive oxygen species in coronary arteries. Circ Res 2001;88:44-51. [PubMed: 11139472]

60. Kukreja RC, Kontos HA, Hess ML, Ellis EF. PGH synthase and lipoxygenase generate superoxide in the presence of NADH or NADPH. Circ Res 1986;59:612-619. [PubMed: 3028671]

61. Boveris A. Mitochondrial production of superoxide radical and hydrogen peroxide. Adv Exp Med Biol 1977;78:67-82. [PubMed: 197811]

62. Shigenaga MK, Hagen TM, Ames BN. Oxidative damage and mitochondrial decay in aging. Proc Natl Acad Sci USA 1994;91:10771-10778. [PubMed: 7971961]

63. Archer SL, Weir EK, Reeve HL, Michelakis E. Molecular identification of O2 sensors and O2sensitive potassium channels in the pulmonary circulation. Adv Exp Med Biol 2000;475:219-240. [PubMed: 10849663]

64. Du XL, Edelstein D, Rossetti L, Fantus IG, Goldberg H, Ziyadeh F, Wu J, Brownlee M. Hyperglycemia-induced mitochondrial superoxide overproduction activates the hexosamine pathway and induces plasminogen activator inhibitor-1 expression by increasing Sp1 glycosylation. Proc Natl Acad Sci USA 2000;97:12222-12226. [PubMed: 11050244]

65. Pearlstein DP, Ali MH, Mungai PT, Hynes KL, Gewertz BL, Schumacker PT. Role of mitochondrial oxidant generation in endothelial cell responses to hypoxia. Arterioscler Thromb Vasc Biol 2002;22:566-573. [PubMed: 11950692]

66. Fridovich I. Superoxide radical: an endogenous toxicant. Annu Rev Pharmacol Toxicol 1983;23:239257. [PubMed: 6307121]

67. Fridovich I. Biological effects of the superoxide radical. Arch Biochem Biophys 1986;247:1-11. [PubMed: 3010872] 
68. Wolin MS, Burke-Wolin TM, Mohazzab HK. Roles for NAD(P)H oxidases and reactive oxygen species in vascular oxygen sensing mechanisms. Respir Physiol 1999;115:229-238. [PubMed: 10385036]

69. Halliwell B. Free radicals, reactive oxygen species and human disease: a critical evaluation with special reference to atherosclerosis. Br J Exp Pathol 1989;70:737-757. [PubMed: 2557883]

70. Kanner J, Harel S, Granit R. Nitric oxide as an antioxidant. Arch Biochem Biophys 1991;289:130136. [PubMed: 1654842]

71. Marshall JJ, Kontos HA. Endothelium-derived relaxing factors. A perspective from in vivo data. Hypertension 1990;16:371-386. [PubMed: 2170274]

72. Rubanyi GM, Vanhoutte PM. Oxygen-derived free radicals, endothelium, and responsiveness of vascular smooth muscle. Am J Physiol 1986;250:H815-H821. [PubMed: 3085520]

73. Rassaf T, Kleinbongard P, Preik M, Dejam A, Gharini P, Lauer T, Erckenbrecht J, Duschin A, Schulz R, Heusch G, Feelisch M, Kelm M. Plasma nitrosothiols contribute to the systemic vasodilator effects of intravenously applied NO: experimental and clinical Study on the fate of NO in human blood. Circ Res 2002;91:470-477. [PubMed: 12242264]

74. Grubina R, Huang Z, Shiva S, Joshi MS, Azarov I, Basu S, Ringwood LA, Jiang A, Hogg N, KimShapiro DB, Gladwin MT. Concerted nitric oxide formation and release from the simultaneous reactions of nitrite with deoxy- and oxyhemoglobin. J Biol Chem 2007;282:12916-12927. [PubMed: 17322300]

75. Zweier JL, Wang P, Samouilov A, Kuppusamy P. Enzyme-independent formation of nitric oxide in biological tissues. Nat Med 1995;1:804-809. [PubMed: 7585184]

76. Auch-Schwelk W, Katusic ZS, Vanhoutte PM. Contractions to oxygen-derived free radicals are augmented in aorta of the spontaneously hypertensive rat. Hypertension 1989;13:859-864. [PubMed: 2567706]

77. Katusic ZS, Schugel J, Cosentino F, Vanhoutte PM. Endothelium-dependent contractions to oxygenderived free radicals in the canine basilar artery. Am J Physiol 1993;264:H859-H864. [PubMed: 8456988]

78. Goodwin DC, Rowlinson SW, Marnett LJ. Substitution of tyrosine for the proximal histidine ligand to the heme of prostaglandin endoperoxide synthase 2: implications for the mechanism of cyclooxygenase activation and catalysis. Biochemistry 2000;39:5422-5432. [PubMed: 10820014]

79. Tesfamariam B. Free radicals in diabetic endothelial cell dysfunction. Free Radic Biol Med 1994;16:383-391. [PubMed: 8063201]

80. Tesfamariam B, Cohen RA. Role of superoxide anion and endothelium in vasoconstrictor action of prostaglandin endoperoxide. Am J Physiol 1992;262:H1915-H1919. [PubMed: 1320340]

81. Sorescu D, Szocs K, Griendling KK. NAD(P)H oxidases and their relevance to atherosclerosis. Trends Cardiovasc Med 2001;11:124-131. [PubMed: 11686001]

82. Mancini GB, Henry GC, Macaya C, O'Neill BJ, Pucillo AL, Carere RG, Wargovich TJ, Mudra H, Luscher TF, Klibaner MI, Haber HE, Uprichard AC, Pepine CJ, Pitt B. Angiotensin-converting enzyme inhibition with quinapril improves endothelial vasomotor dysfunction in patients with coronary artery disease. The TREND (Trial on Reversing ENdothelial Dysfunction) Study. Circulation 1996;94:258-265. [PubMed: 8759064]

83. Munzel T, Keaney JF Jr. Are ACE inhibitors a "magic bullet" against oxidative stress? Circulation 2001;104:1571-1574. [PubMed: 11571254]

84. Kunsch C, Medford RM. Oxidative stress as a regulator of gene expression in the vasculature. Circ Res 1999;85:753-766. [PubMed: 10521248]

85. Wolin MS. Interactions of oxidants with vascular signaling systems. Arterioscler Thromb Vasc Biol 2000;20:1430-1442. [PubMed: 10845855]

86. Lounsbury KM, Hu Q, Ziegelstein RC. Calcium signaling and oxidant stress in the vasculature. Free Radic Biol Med 2000;28:1362-1369. [PubMed: 10924855]

87. Suzuki YJ, Packer L, Ford GD. Relationships between the effects of superoxide anion and palmitoylL-carnitine on the $\mathrm{Ca}(2+)$-ATPase of vascular smooth muscle sarcoplasmic reticulum. J Mol Cell Cardiol 1993;25:823-827. [PubMed: 8230244] 
88. Iesaki T, Wolin MS. Thiol oxidation activates a novel redox-regulated coronary vasodilator mechanism involving inhibition of Ca2+ influx. Arterioscler Thromb Vasc Biol 2000;20:2359-2365. [PubMed: 11073838]

89. Zhong J, Hume JR, Keef KD. beta-Adrenergic receptor stimulation of L-type Ca2+ channels in rabbit portal vein myocytes involves both alphas and betagamma $\mathrm{G}$ protein subunits. J Physiol 2001;531:105-115. [PubMed: 11179395]

90. Kooy NW, Royall JA. Agonist-induced peroxynitrite production from endothelial cells. Arch Biochem Biophys 1994;310:352-359. [PubMed: 8179319]

91. Liu Y, Terata K, Rusch NJ, Gutterman DD. High glucose impairs voltage-gated K(+) channel current in rat small coronary arteries. Circ Res 2001;89:146-152. [PubMed: 11463721]

92. Tokube K, Kiyosue T, Arita M. Effects of hydroxyl radicals on KATP channels in guinea-pig ventricular myocytes. Pflugers Arch 1998;437:155-157. [PubMed: 9817800]

93. Mukhopadhyay CK, Fox PL. Ceruloplasmin copper induces oxidant damage by a redox process utilizing cell-derived superoxide as reductant. Biochemistry 1998;37:14222-14229. [PubMed: 9760260]

94. Podrez EA, Abu-Soud HM, Hazen SL. Myeloperoxidase-generated oxidants and atherosclerosis. Free Radic Biol Med 2000;28:1717-1725. [PubMed: 10946213]

95. Jin N, Rhoades RA. Activation of tyrosine kinases in H2O2-induced contraction in pulmonary artery. Am J Physiol 1997;272:H2686-H2692. [PubMed: 9227547]

96. Sundaresan M, Yu ZX, Ferrans VJ, Irani K, Finkel T. Requirement for generation of H2O2 for plateletderived growth factor signal transduction. Science 1995;270:296-299. [PubMed: 7569979]

97. Davies KJ. Oxidative stress: the paradox of aerobic life. Biochem Soc Symp 1995;61:1-31. [PubMed: 8660387]

98. Vertuani S, Angusti A, Manfredini S. The antioxidants and pro-antioxidants network: an overview. Curr Pharm Des 2004;10:1677-1694. [PubMed: 15134565]

99. Sies H. Oxidative stress: oxidants and antioxidants. Exp Physiol 1997;82:291-295. [PubMed: 9129943]

100. Wells WW, Xu DP, Yang YF, Rocque PA. Mammalian thioltransferase (glutaredoxin) and protein disulfide isomerase have dehydroascorbate reductase activity. J Biol Chem 1990;265:1536115364. [PubMed: 2394726]

101. Padayatty SJ, Katz A, Wang Y, Eck P, Kwon O, Lee JH, Chen S, Corpe C, Dutta A, Dutta SK, Levine M. Vitamin C as an antioxidant: evaluation of its role in disease prevention. J Am Coll Nutr 2003;22:18-35. [PubMed: 12569111]

102. Carr A, Frei B. Does vitamin C act as a pro-oxidant under physiological conditions? FASEB J 1999;13:1007-1024. [PubMed: 10336883]

103. Taddei S, Virdis A, Ghiadoni L, Magagna A, Salvetti A. Vitamin C improves endothelium-dependent vasodilation by restoring nitric oxide activity in essential hypertension. Circulation 1998;97:22222229. [PubMed: 9631871]

104. Ting HH, Timimi FK, Haley EA, Roddy MA, Ganz P, Creager MA. Vitamin C improves endothelium-dependent vasodilation in forearm resistance vessels of humans with hypercholesterolemia. Circulation 1997;95:2617-2622. [PubMed: 9193429]

105. Herrera E, Barbas C. Vitamin E: action, metabolism and perspectives. J Physiol Biochem 2001;57:43-56.

106. Brigelius-Flohe R, Traber MG. Vitamin E: function and metabolism. FASEB J 1999;13:1145-1155. [PubMed: 10385606]

107. Wang X, Quinn PJ. Vitamin E and its function in membranes. Prog Lipid Res 1999;38:309-336. [PubMed: 10793887]

108. Sen CK, Khanna S, Roy S. Tocotrienols: Vitamin E beyond tocopherols. Life Sci 2006;78:20882098. [PubMed: 16458936]

109. Zingg JM. Modulation of signal transduction by vitamin E. Mol Aspects Med Oct-Dec;2007 28(56): 400-22. [PubMed: 17624418]Epub 2007 Jun 2 
110. Stephens NG, Parsons A, Schofield PM, Kelly F, Cheeseman K, Mitchinson MJ. Randomised controlled trial of vitamin E in patients with coronary disease: Cambridge Heart Antioxidant Study (CHAOS). Lancet 1996;347:781-786. [PubMed: 8622332]

111. Yusuf S, Dagenais G, Pogue J, Bosch J, Sleight P. Vitamin E supplementation and cardiovascular events in high-risk patients. The Heart Outcomes Prevention Evaluation Study Investigators. N Engl J Med 2000;342:154-160. [PubMed: 10639540]

112. Brown BG, Zhao XQ, Chait A, Fisher LD, Cheung MC, Morse JS, Dowdy AA, Marino EK, Bolson EL, Alaupovic P, Frohlich J, Albers JJ. Simvastatin and niacin, antioxidant vitamins, or the combination for the prevention of coronary disease. N Engl J Med 2001;345:1583-1592. [PubMed: 11757504]

113. Lonn E, Bosch J, Yusuf S, Sheridan P, Pogue J, Arnold JM, Ross C, Arnold A, Sleight P, Probstfield J, Dagenais GR. Effects of long-term vitamin E supplementation on cardiovascular events and cancer: a randomized controlled trial. JAMA 2005;293:1338-1347. [PubMed: 15769967]

114. Meister A, Anderson ME. Glutathione. Annu Rev Biochem 1983;52:711-760. [PubMed: 6137189]

115. Meister A. Glutathione metabolism and its selective modification. J Biol Chem 1988;263:1720517208. [PubMed: 3053703]

116. Meister A. Glutathione-ascorbic acid antioxidant system in animals. J Biol Chem 1994;269:93979400. [PubMed: 8144521]

117. Ma XL, Lopez BL, Liu GL, Christopher TA, Gao F, Guo Y, Feuerstein GZ, Ruffolo RR Jr. Barone FC, Yue TL. Hypercholesterolemia impairs a detoxification mechanism against peroxynitrite and renders the vascular tissue more susceptible to oxidative injury. Circ Res 1997;80:894-901. [PubMed: 9168793]

118. Rubanyi GM, Vanhoutte PM. Superoxide anions and hyperoxia inactivate endothelium-derived relaxing factor. Am J Physiol 1986;250:H822-H827. [PubMed: 3010744]

119. Gryglewski RJ, Palmer RM, Moncada S. Superoxide anion is involved in the breakdown of endothelium-derived vascular relaxing factor. Nature 1986;320:454-456. [PubMed: 3007998]

120. Goldstein S, Czapski G. The reaction of NO. with O2.- and HO2.: a pulse radiolysis study. Free Radic Biol Med 1995;19:505-510. [PubMed: 7590401]

121. Gow AJ, Ischiropoulos H. Nitric oxide chemistry and cellular signaling. J Cell Physiol 2001;187:277-282. [PubMed: 11319751]

122. Sampson JB, Beckman JS. Hydrogen peroxide damages the zinc-binding site of zinc-deficient $\mathrm{Cu}, \mathrm{Zn}$ superoxide dismutase. Arch Biochem Biophys 2001;392:8-13. [PubMed: 11469788]

123. Rowland LP, Shneider NA. Amyotrophic lateral sclerosis. N Engl J Med 2001;344:1688-1700. [PubMed: 11386269]

124. Brown GC. Nitric oxide and mitochondrial respiration. Biochim Biophys Acta 1999;1411:351-369. [PubMed: 10320668]

125. Inoue N, Ramasamy S, Fukai T, Nerem RM, Harrison DG. Shear stress modulates expression of $\mathrm{Cu} / \mathrm{Zn}$ superoxide dismutase in human aortic endothelial cells. Circ Res 1996;79:32-37. [PubMed: 8925565]

126. Stralin P, Karlsson K, Johansson BO, Marklund SL. The interstitium of the human arterial wall contains very large amounts of extracellular superoxide dismutase. Arterioscler Thromb Vasc Biol 1995;15:2032-2036. [PubMed: 7583586]

127. Chelikani P, Fita I, Loewen PC. Diversity of structures and properties among catalases. Cell Mol Life Sci 2004;61:192-208. [PubMed: 14745498]

128. del Rio LA, Sandalio LM, Palma JM, Bueno P, Corpas FJ. Metabolism of oxygen radicals in peroxisomes and cellular implications. Free Radic Biol Med 1992;13:557-580. [PubMed: 1334030]

129. Rhee SG, Chae HZ, Kim K. Peroxiredoxins: a historical overview and speculative preview of novel mechanisms and emerging concepts in cell signaling. Free Radic Biol Med 2005;38:1543-1552. [PubMed: 15917183]

130. Wood ZA, Schroder E, Robin Harris J, Poole LB. Structure, mechanism and regulation of peroxiredoxins. Trends Biochem Sci 2003;28:32-40. [PubMed: 12517450]

131. Claiborne A, Yeh JI, Mallett TC, Luba J, Crane EJ 3rd, Charrier V, Parsonage D. Protein-sulfenic acids: diverse roles for an unlikely player in enzyme catalysis and redox regulation. Biochemistry 1999;38:15407-15416. [PubMed: 10569923] 
132. Yamawaki H, Haendeler J, Berk BC. Thioredoxin: a key regulator of cardiovascular homeostasis. Circ Res 2003;93:1029-1033. [PubMed: 14645133]

133. Nordberg J, Arner ES. Reactive oxygen species, antioxidants, and the mammalian thioredoxin system. Free Radic Biol Med 2001;31:1287-312. [PubMed: 11728801]

134. Arner ES, Holmgren A. Physiological functions of thioredoxin and thioredoxin reductase. Eur J Biochem 2000;267:6102-6109. [PubMed: 11012661]

135. Mustacich D, Powis G. Thioredoxin reductase. Biochem J 2000;346(Pt 1):1-8. [PubMed: 10657232]

136. Brigelius-Flohe R. Tissue-specific functions of individual glutathione peroxidases. Free Radic Biol Med 1999;27:951-965. [PubMed: 10569628]

137. Sies H, Sharov VS, Klotz LO, Briviba K. Glutathione peroxidase protects against peroxynitritemediated oxidations. A new function for selenoproteins as peroxynitrite reductase. J Biol Chem 1997;272:27812-27817. [PubMed: 9346926]

138. Sharma R, Yang Y, Sharma A, Awasthi S, Awasthi YC. Antioxidant role of glutathione Stransferases: protection against oxidant toxicity and regulation of stress-mediated apoptosis. Antioxid Redox Signal 2004;6:289-300. [PubMed: 15025930]

139. Perrella MA, Yet SF. Role of heme oxygenase-1 in cardiovascular function. Curr Pharm Des 2003;9:2479-2487. [PubMed: 14529547]

140. Murad F. Nitric oxide signaling: would you believe that a simple free radical could be a second messenger, autacoid, paracrine substance, neurotransmitter, and hormone? Recent Prog Horm Res 1998;53:43-59. [PubMed: 9769702]discussion 59-60

141. Hanafy KA, Krumenacker JS, Murad F. NO, nitrotyrosine, and cyclic GMP in signal transduction. Med Sci Monit 2001;7:801-819. [PubMed: 11433215]

142. Padmaja S, Huie RE. The reaction of nitric oxide with organic peroxyl radicals. Biochem Biophys Res Commun 1993;195:539-544. [PubMed: 8373394]

143. Cleeter MW, Cooper JM, Darley-Usmar VM, Moncada S, Schapira AH. Reversible inhibition of cytochrome c oxidase, the terminal enzyme of the mitochondrial respiratory chain, by nitric oxide. Implications for neurodegenerative diseases. FEBS Lett 1994;345:50-54. [PubMed: 8194600]

144. Eich RF, Li T, Lemon DD, Doherty DH, Curry SR, Aitken JF, Mathews AJ, Johnson KA, Smith RD, Phillips GN Jr. Olson JS. Mechanism of NO-induced oxidation of myoglobin and hemoglobin. Biochemistry 1996;35:6976-6983. [PubMed: 8679521]

145. Pryor WA, Stone K. Oxidants in cigarette smoke. Radicals, hydrogen peroxide, peroxynitrate, and peroxynitrite. Ann N Y Acad Sci 1993;686:12-27. [PubMed: 8512242]discussion 27-28

146. Moncada S, Higgs EA. Endogenous nitric oxide: physiology, pathology and clinical relevance. Eur J Clin Invest 1991;21:361-374. [PubMed: 1718757]

147. Lipton SA. Neuronal protection and destruction by NO. Cell Death Differ 1999;6:943-951. [PubMed: 10556970]

148. Joannides R, Haefeli WE, Linder L, Richard V, Bakkali EH, Thuillez C, Luscher TF. Nitric oxide is responsible for flow-dependent dilatation of human peripheral conduit arteries in vivo. Circulation 1995;91:1314-1319. [PubMed: 7867167]

149. Nathan C, Xie QW. Regulation of biosynthesis of nitric oxide. J Biol Chem 1994;269:13725-13728. [PubMed: 7514592]

150. Stuehr DJ. Mammalian nitric oxide synthases. Biochim Biophys Acta 1999;1411:217-230. [PubMed: 10320659]

151. Wang Y, Newton DC, Marsden PA. Neuronal NOS: gene structure, mRNA diversity, and functional relevance. Crit Rev Neurobiol 1999;13:21-43. [PubMed: 10223522]

152. Doyle MP, Hoekstra JW. Oxidation of nitrogen oxides by bound dioxygen in hemoproteins. J Inorg Biochem 1981;14:351-358. [PubMed: 7276933]

153. Bolotina VM, Najibi S, Palacino JJ, Pagano PJ, Cohen RA. Nitric oxide directly activates calciumdependent potassium channels in vascular smooth muscle. Nature 1994;368:850-853. [PubMed: 7512692]

154. Cohen RA, Weisbrod RM, Gericke M, Yaghoubi M, Bierl C, Bolotina VM. Mechanism of nitric oxide-induced vasodilatation: refilling of intracellular stores by sarcoplasmic reticulum $\mathrm{Ca} 2+$ 
ATPase and inhibition of store-operated Ca2+ influx. Circ Res 1999;84:210-219. [PubMed: 9933253]

155. Horowitz A, Menice CB, Laporte R, Morgan KG. Mechanisms of smooth muscle contraction. Physiol Rev 1996;76:967-1003. [PubMed: 8874491]

156. Stamler JS, Singel DJ, Loscalzo J. Biochemistry of nitric oxide and its redox-activated forms. Science 1992;258:1898-1902. [PubMed: 1281928]

157. Wink DA, Nims RW, Darbyshire JF, Christodoulou D, Hanbauer I, Cox GW, Laval F, Laval J, Cook JA, Krishna MC, et al. Reaction kinetics for nitrosation of cysteine and glutathione in aerobic nitric oxide solutions at neutral $\mathrm{pH}$. Insights into the fate and physiological effects of intermediates generated in the NO/O2 reaction. Chem Res Toxicol 1994;7:519-525. [PubMed: 7981416]

158. Stamler JS, Jaraki O, Osborne J, Simon DI, Keaney J, Vita J, Singel D, Valeri CR, Loscalzo J. Nitric oxide circulates in mammalian plasma primarily as an S-nitroso adduct of serum albumin. Proc Natl Acad Sci USA 1992;89:7674-7677. [PubMed: 1502182]

159. Challis BC, Edwards A, Hunma RR, Kyrtopoulos SA, Outram JR. Rapid formation of Nnitrosamines from nitrogen oxides under neutral and alkaline conditions. IARC Sci Publ 1978;19:127-42. [PubMed: 28274]

160. Tannenbaum SR, Wishnok JS, Leaf CD. Inhibition of nitrosamine formation by ascorbic acid. Am J Clin Nutr 1991;53:247S-250S. [PubMed: 1985394]

161. Zhang YY, Xu AM, Nomen M, Walsh M, Keaney JF Jr. Loscalzo J. Nitrosation of tryptophan residue (s) in serum albumin and model dipeptides. Biochemical characterization and bioactivity. J Biol Chem 1996;271:14271-14279. [PubMed: 8662958]

162. Wink DA, Kasprzak KS, Maragos CM, Elespuru RK, Misra M, Dunams TM, Cebula TA, Koch WH, Andrews AW, Allen JS, et al. DNA deaminating ability and genotoxicity of nitric oxide and its progenitors. Science 1991;254:1001-1003. [PubMed: 1948068]

163. Rodriguez J, Maloney RE, Rassaf T, Bryan NS, Feelisch M. Chemical nature of nitric oxide storage forms in rat vascular tissue. Proc Natl Acad Sci USA 2003;100:336-341. [PubMed: 12502793]

164. Boger RH, Bode-Boger SM, Kienke S, Stan AC, Nafe R, Frolich JC. Dietary L-arginine decreases myointimal cell proliferation and vascular monocyte accumulation in cholesterol-fed rabbits. Atherosclerosis 1998;136:67-77. [PubMed: 9544733]

165. Bult H. Nitric oxide and atherosclerosis: possible implications for therapy. Mol Med Today 1996;2:510-518. [PubMed: 9015792]

166. Busse R, Luckhoff A, Bassenge E. Endothelium-derived relaxant factor inhibits platelet activation. Naunyn Schmiedebergs Arch Pharmacol 1987;336:566-571. [PubMed: 2830546]

167. Ware JA, Heistad DD. Seminars in medicine of the Beth Israel Hospital, Boston. Plateletendothelium interactions. N Engl J Med 1993;328:628-635. [PubMed: 8429855]

168. Battinelli E, Loscalzo J. Nitric oxide induces apoptosis in megakaryocytic cell lines. Blood 2000;95:3451-3459. [PubMed: 10828028]

169. Trepakova ES, Cohen RA, Bolotina VM. Nitric oxide inhibits capacitative cation influx in human platelets by promoting sarcoplasmic/endoplasmic reticulum Ca2+-ATPase-dependent refilling of Ca2+ stores. Circ Res 1999;84:201-209. [PubMed: 9933252]

170. Moro MA, Russel RJ, Cellek S, Lizasoain I, Su Y, Darley-Usmar VM, Radomski MW, Moncada S. cGMP mediates the vascular and platelet actions of nitric oxide: confirmation using an inhibitor of the soluble guanylyl cyclase. Proc Natl Acad Sci USA 1996;93:1480-1485. [PubMed: 8643658]

171. Radomski MW, Palmer RM, Moncada S. An L-arginine/nitric oxide pathway present in human platelets regulates aggregation. Proc Natl Acad Sci USA 1990;87:5193-5197. [PubMed: 1695013]

172. Michelson AD, Benoit SE, Furman MI, Breckwoldt WL, Rohrer MJ, Barnard MR, Loscalzo J. Effects of nitric oxide/EDRF on platelet surface glycoproteins. Am J Physiol 1996;270:H1640H1648. [PubMed: 8928869]

173. Murohara T, Parkinson SJ, Waldman SA, Lefer AM. Inhibition of nitric oxide biosynthesis promotes P-selectin expression in platelets. Role of protein kinase C. Arterioscler Thromb Vasc Biol 1995;15:2068-2075. [PubMed: 7583591]

174. Walford G, Loscalzo J. Nitric oxide in vascular biology. J Thromb Haemost 2003;1:2112-2118. [PubMed: 14521592] 
175. Bath PM, Hassall DG, Gladwin AM, Palmer RM, Martin JF. Nitric oxide and prostacyclin. Divergence of inhibitory effects on monocyte chemotaxis and adhesion to endothelium in vitro. Arterioscler Thromb 1991;11:254-260. [PubMed: 1847823]

176. De Caterina R, Libby P, Peng HB, Thannickal VJ, Rajavashisth TB, Gimbrone MA Jr. Shin WS, Liao JK. Nitric oxide decreases cytokine-induced endothelial activation. Nitric oxide selectively reduces endothelial expression of adhesion molecules and proinflammatory cytokines. J Clin Invest 1995;96:60-68. [PubMed: 7542286]

177. Welch GN, Upchurch G Jr. Loscalzo J. Hyperhomocyst(e)inemia and atherothrombosis. Ann N Y Acad Sci 1997;811:48-58. [PubMed: 9186584]discussion 58-59

178. Welch GN, Upchurch GR Jr. Loscalzo J. Homocysteine, oxidative stress, and vascular disease. Hosp Pract (Minneap) 1997;32:81-82. [PubMed: 9194803]85, 88-92

179. Forgione MA, Weiss N, Heydrick S, Cap A, Klings ES, Bierl C, Eberhardt RT, Farber HW, Loscalzo J. Cellular glutathione peroxidase deficiency and endothelial dysfunction. Am J Physiol Heart Circ Physiol 2002;282:H1255-H1261. [PubMed: 11893559]

180. Folcik VA, Nivar-Aristy RA, Krajewski LP, Cathcart MK. Lipoxygenase contributes to the oxidation of lipids in human atherosclerotic plaques. J Clin Invest 1995;96:504-510. [PubMed: 7615823]

181. Cyrus T, Witztum JL, Rader DJ, Tangirala R, Fazio S, Linton MF, Funk CD. Disruption of the 12/15-lipoxygenase gene diminishes atherosclerosis in apo E-deficient mice. J Clin Invest 1999;103:1597-1604. [PubMed: 10359569]

182. Shen J, Herderick E, Cornhill JF, Zsigmond E, Kim HS, Kuhn H, Guevara NV, Chan L. Macrophagemediated 15-lipoxygenase expression protects against atherosclerosis development. J Clin Invest 1996;98:2201-2208. [PubMed: 8941635]

183. Daugherty A, Dunn JL, Rateri DL, Heinecke JW. Myeloperoxidase, a catalyst for lipoprotein oxidation, is expressed in human atherosclerotic lesions. J Clin Invest 1994;94:437-444. [PubMed: 8040285]

184. Sparrow CP, Parthasarathy S, Steinberg D. Enzymatic modification of low density lipoprotein by purified lipoxygenase plus phospholipase A2 mimics cell-mediated oxidative modification. J Lipid Res 1988;29:745-753. [PubMed: 3139813]

185. Panasenko OM, Briviba K, Klotz LO, Sies H. Oxidative modification and nitration of human lowdensity lipoproteins by the reaction of hypochlorous acid with nitrite. Arch Biochem Biophys 1997;343:254-259. [PubMed: 9224738]

186. Witztum JL. The oxidation hypothesis of atherosclerosis. Lancet 1994;344:793-795. [PubMed: 7916078]

187. Westhuyzen J. The oxidation hypothesis of atherosclerosis: an update. Ann Clin Lab Sci 1997;27:110. [PubMed: 8997452]

188. Steinberg D, Parthasarathy S, Carew TE, Khoo JC, Witztum JL. Beyond cholesterol. Modifications of low-density lipoprotein that increase its atherogenicity. N Engl J Med 1989;320:915-924. [PubMed: 2648148]

189. Graham A, Hogg N, Kalyanaraman B, O'Leary V, Darley-Usmar V, Moncada S. Peroxynitrite modification of low-density lipoprotein leads to recognition by the macrophage scavenger receptor. FEBS Lett 1993;330:181-185. [PubMed: 8365489]

190. Podrez EA, Schmitt D, Hoff HF, Hazen SL. Myeloperoxidase-generated reactive nitrogen species convert LDL into an atherogenic form in vitro. J Clin Invest 1999;103:1547-1560. [PubMed: 10359564]

191. Panasenko OM, Sharov VS, Briviba K, Sies H. Interaction of peroxynitrite with carotenoids in human low density lipoproteins. Arch Biochem Biophys 2000;373:302-305. [PubMed: 10620353]

192. Witztum JL, Steinberg D. Role of oxidized low density lipoprotein in atherogenesis. J Clin Invest 1991;88:1785-1792. [PubMed: 1752940]

193. Ushio-Fukai M, Alexander RW, Akers M, Yin Q, Fujio Y, Walsh K, Griendling KK. Reactive oxygen species mediate the activation of Akt/protein kinase B by angiotensin II in vascular smooth muscle cells. J Biol Chem 1999;274:22699-22704. [PubMed: 10428852]

194. Navab M, Imes SS, Hama SY, Hough GP, Ross LA, Bork RW, Valente AJ, Berliner JA, Drinkwater DC, Laks H, et al. Monocyte transmigration induced by modification of low density lipoprotein in 
cocultures of human aortic wall cells is due to induction of monocyte chemotactic protein 1 synthesis and is abolished by high density lipoprotein. J Clin Invest 1991;88:2039-2046. [PubMed: 1752961]

195. Marumo T, Schini-Kerth VB, Fisslthaler B, Busse R. Platelet-derived growth factor-stimulated superoxide anion production modulates activation of transcription factor NF-kappaB and expression of monocyte chemoattractant protein 1 in human aortic smooth muscle cells. Circulation 1997;96:2361-2367. [PubMed: 9337212]

196. Valen G, Yan ZQ, Hansson GK. Nuclear factor kappa-B and the heart. J Am Coll Cardiol 2001;38:307-14. [PubMed: 11499717]

197. Galis ZS, Asanuma K, Godin D, Meng X. N-acetyl-cysteine decreases the matrix-degrading capacity of macrophage-derived foam cells: new target for antioxidant therapy? Circulation 1998;97:24452453. [PubMed: 9641697]

198. Channon KM. Oxidative stress and coronary plaque stability. Arterioscler Thromb Vasc Biol 2002;22:1751-1752. [PubMed: 12426198]

199. Azumi H, Inoue N, Ohashi Y, Terashima M, Mori T, Fujita H, Awano K, Kobayashi K, Maeda K, Hata K, Shinke T, Kobayashi S, Hirata K, Kawashima S, Itabe H, Hayashi Y, Imajoh-Ohmi S, Itoh $\mathrm{H}$, Yokoyama M. Superoxide generation in directional coronary atherectomy specimens of patients with angina pectoris: important role of $\mathrm{NAD}(\mathrm{P}) \mathrm{H}$ oxidase. Arterioscler Thromb Vasc Biol 2002;22:1838-1844. [PubMed: 12426213]

200. Ohara Y, Peterson TE, Harrison DG. Hypercholesterolemia increases endothelial superoxide anion production. J Clin Invest 1993;91:2546-2551. [PubMed: 8390482]

201. Mugge A, Elwell JH, Peterson TE, Hofmeyer TG, Heistad DD, Harrison DG. Chronic treatment with polyethylene-glycolated superoxide dismutase partially restores endothelium-dependent vascular relaxations in cholesterol-fed rabbits. Circ Res 1991;69:1293-1300. [PubMed: 1934359]

202. Guzik TJ, West NE, Black E, McDonald D, Ratnatunga C, Pillai R, Channon KM. Vascular superoxide production by NAD(P)H oxidase: association with endothelial dysfunction and clinical risk factors. Circ Res 2000;86:E85-E90. [PubMed: 10807876]

203. Buttery LD, Springall DR, Chester AH, Evans TJ, Standfield EN, Parums DV, Yacoub MH, Polak JM. Inducible nitric oxide synthase is present within human atherosclerotic lesions and promotes the formation and activity of peroxynitrite. Lab Invest 1996;75:77-85. [PubMed: 8683942]

204. Beckman JS, Beckman TW, Chen J, Marshall PA, Freeman BA. Apparent hydroxyl radical production by peroxynitrite: implications for endothelial injury from nitric oxide and superoxide. Proc Natl Acad Sci USA 1990;87:1620-1624. [PubMed: 2154753]

205. Pryor WA, Squadrito GL. The chemistry of peroxynitrite: a product from the reaction of nitric oxide with superoxide. Am J Physiol 1995;268:L699-L722. [PubMed: 7762673]

206. Traylor TG, Sharma VS. Why NO? Biochemistry 1992;31:2847-2849. [PubMed: 1348002]

207. Gorren AC, de Boer E, Wever R. The reaction of nitric oxide with copper proteins and the photodissociation of copper-NO complexes. Biochim Biophys Acta 1987;916:38-47. [PubMed: 2822126]

208. Rubbo H, Radi R, Trujillo M, Telleri R, Kalyanaraman B, Barnes S, Kirk M, Freeman BA. Nitric oxide regulation of superoxide and peroxynitrite-dependent lipid peroxidation. Formation of novel nitrogen-containing oxidized lipid derivatives. J Biol Chem 1994;269:26066-26075. [PubMed: 7929318]

209. Wink DA, Hanbauer I, Krishna MC, DeGraff W, Gamson J, Mitchell JB. Nitric oxide protects against cellular damage and cytotoxicity from reactive oxygen species. Proc Natl Acad Sci USA 1993;90:9813-9817. [PubMed: 8234317]

210. Packer MA, Scarlett JL, Martin SW, Murphy MP. Induction of the mitochondrial permeability transition by peroxynitrite. Biochem Soc Trans 1997;25:909-914. [PubMed: 9388571]

211. Poderoso JJ, Carreras MC, Lisdero C, Riobo N, Schopfer F, Boveris A. Nitric oxide inhibits electron transfer and increases superoxide radical production in rat heart mitochondria and submitochondrial particles. Arch Biochem Biophys 1996;328:85-92. [PubMed: 8638942]

212. MacMillan-Crow LA, Crow JP, Kerby JD, Beckman JS, Thompson JA. Nitration and inactivation of manganese superoxide dismutase in chronic rejection of human renal allografts. Proc Natl Acad Sci USA 1996;93:11853-8. [PubMed: 8876227] 
213. Wolin MS, Hintze TH, Shen W, Mohazzab HK, Xie YW. Involvement of reactive oxygen and nitrogen species in signalling mechanisms that control tissue respiration in muscle. Biochem Soc Trans 1997;25:934-939. [PubMed: 9388576]

214. Radi R, Beckman JS, Bush KM, Freeman BA. Peroxynitrite oxidation of sulfhydryls. The cytotoxic potential of superoxide and nitric oxide. J Biol Chem 1991;266:4244-4250. [PubMed: 1847917]

215. Koppenol WH, Moreno JJ, Pryor WA, Ischiropoulos H, Beckman JS. Peroxynitrite, a cloaked oxidant formed by nitric oxide and superoxide. Chem Res Toxicol 1992;5:834-842. [PubMed: 1336991]

216. Saran M, Bors W. Signalling by O2-. and NO.: how far can either radical, or any specific reaction product, transmit a message under in vivo conditions? Chem Biol Interact 1994;90:35-45. [PubMed: 8131218]

217. Pacher P, Beckman JS, Liaudet L. Nitric oxide and peroxynitrite in health and disease. Physiol Rev 2007;87:315-424. [PubMed: 17237348]

218. Moreno JJ, Pryor WA. Inactivation of alpha 1-proteinase inhibitor by peroxynitrite. Chem Res Toxicol 1992;5:425-431. [PubMed: 1504267]

219. Radi R, Beckman JS, Bush KM, Freeman BA. Peroxynitrite-induced membrane lipid peroxidation: the cytotoxic potential of superoxide and nitric oxide. Arch Biochem Biophys 1991;288:481-487. [PubMed: 1654835]

220. Yermilov V, Rubio J, Ohshima H. Formation of 8-nitroguanine in DNA treated with peroxynitrite in vitro and its rapid removal from DNA by depurination. FEBS Lett 1995;376:207-210. [PubMed: 7498543]

221. Inoue S, Kawanishi S. Oxidative DNA damage induced by simultaneous generation of nitric oxide and superoxide. FEBS Lett 1995;371:86-88. [PubMed: 7664890]

222. Quijano C, Alvarez B, Gatti RM, Augusto O, Radi R. Pathways of peroxynitrite oxidation of thiol groups. Biochem J 1997;322(Pt 1):167-173. [PubMed: 9078258]

223. Radi R, Bush KM, Cosgrove TP, Freeman BA. Reaction of xanthine oxidase-derived oxidants with lipid and protein of human plasma. Arch Biochem Biophys 1991;286:117-125. [PubMed: 1897941]

224. Hu P, Ischiropoulos H, Beckman JS, Matalon S. Peroxynitrite inhibition of oxygen consumption and sodium transport in alveolar type II cells. Am J Physiol 1994;266:L628-L634. [PubMed: 8023951]

225. Bauer ML, Beckman JS, Bridges RJ, Fuller CM, Matalon S. Peroxynitrite inhibits sodium uptake in rat colonic membrane vesicles. Biochim Biophys Acta 1992;1104:87-94. [PubMed: 1550856]

226. Ishida H, Ichimori K, Hirota Y, Fukahori M, Nakazawa H. Peroxynitrite-induced cardiac myocyte injury. Free Radic Biol Med 1996;20:343-350. [PubMed: 8720904]

227. Salgo MG, Stone K, Squadrito GL, Battista JR, Pryor WA. Peroxynitrite causes DNA nicks in plasmid pBR322. Biochem Biophys Res Commun 1995;210:1025-1030. [PubMed: 7763229]

228. Szabo C, Ohshima H. DNA damage induced by peroxynitrite: subsequent biological effects. Nitric Oxide 1997;1:373-385. [PubMed: 9441908]

229. Liu RH, Hotchkiss JH. Potential genotoxicity of chronically elevated nitric oxide: a review. Mutat Res 1995;339:73-89. [PubMed: 7791803]

230. Reed DJ. Glutathione: toxicological implications. Annu Rev Pharmacol Toxicol 1990;30:603-631. [PubMed: 2188580]

231. Alvarez B, Radi R. Peroxynitrite reactivity with amino acids and proteins. Amino Acids 2003;25:295-311. [PubMed: 14661092]

232. Ducrocq C, Blanchard B, Pignatelli B, Ohshima H. Peroxynitrite: an endogenous oxidizing and nitrating agent. Cell Mol Life Sci 1999;55:1068-1077. [PubMed: 10442088]

233. Wink DA, Darbyshire JF, Nims RW, Saavedra JE, Ford PC. Reactions of the bioregulatory agent nitric oxide in oxygenated aqueous media: determination of the kinetics for oxidation and nitrosation by intermediates generated in the NO/O2 reaction. Chem Res Toxicol 1993;6:23-27. [PubMed: 8448345]

234. Beckman JS, Ischiropoulos H, Zhu L, van der Woerd M, Smith C, Chen J, Harrison J, Martin JC, Tsai M. Kinetics of superoxide dismutase- and iron-catalyzed nitration of phenolics by peroxynitrite. Arch Biochem Biophys 1992;298:438-445. [PubMed: 1416975] 
235. Lipton SA, Choi YB, Pan ZH, Lei SZ, Chen HS, Sucher NJ, Loscalzo J, Singel DJ, Stamler JS. A redox-based mechanism for the neuroprotective and neurodestructive effects of nitric oxide and related nitroso-compounds. Nature 1993;364:626-632. [PubMed: 8394509]

236. Mayer B, Schrammel A, Klatt P, Koesling D, Schmidt K. Peroxynitrite-induced accumulation of cyclic GMP in endothelial cells and stimulation of purified soluble guanylyl cyclase. Dependence on glutathione and possible role of S-nitrosation. J Biol Chem 1995;270:17355-17360. [PubMed: 7615539]

237. Sampson JB, Rosen H, Beckman JS. Peroxynitrite-dependent tyrosine nitration catalyzed by superoxide dismutase, myeloperoxidase, and horseradish peroxidase. Methods Enzymol 1996;269:210-218. [PubMed: 8791651]

238. Pryor WA, Jin X, Squadrito GL. One- and two-electron oxidations of methionine by peroxynitrite. Proc Natl Acad Sci USA 1994;91:11173-11177. [PubMed: 7972029]

239. Ischiropoulos H. Biological selectivity and functional aspects of protein tyrosine nitration. Biochem Biophys Res Commun 2003;305:776-783. [PubMed: 12763060]

240. Radi R. Nitric oxide, oxidants, and protein tyrosine nitration. Proc Natl Acad Sci USA 2004;101:4003-4008. [PubMed: 15020765]

241. Beckman JS, Chen J, Ischiropoulos H, Crow JP. Oxidative chemistry of peroxynitrite. Methods Enzymol 1994;233:229-240. [PubMed: 8015460]

242. Kong LY, McMillian MK, Maronpot R, Hong JS. Protein tyrosine kinase inhibitors suppress the production of nitric oxide in mixed glia, microglia-enriched or astrocyte-enriched cultures. Brain Res 1996;729:102-109. [PubMed: 8874881]

243. Li X, De Sarno P, Song L, Beckman JS, Jope RS. Peroxynitrite modulates tyrosine phosphorylation and phosphoinositide signalling in human neuroblastoma SH-SY5Y cells: attenuated effects in human 1321N1 astrocytoma cells. Biochem J 1998;331(Pt 2):599-606. [PubMed: 9531503]

244. Ellman G, Lysko H. A precise method for the determination of whole blood and plasma sulfhydryl groups. Anal Biochem 1979;93:98-102. [PubMed: 434474]

245. Darley-Usmar VM, Hogg N, O'Leary VJ, Wilson MT, Moncada S. The simultaneous generation of superoxide and nitric oxide can initiate lipid peroxidation in human low density lipoprotein. Free Radic Res Commun 1992;17:9-20. [PubMed: 1332919]

246. Laskey RE, Mathews WR. Nitric oxide inhibits peroxynitrite-induced production of hydroxyeicosatetraenoic acids and F2-isoprostanes in phosphatidylcholine liposomes. Arch Biochem Biophys 1996;330:193-198. [PubMed: 8651696]

247. Moore KP, Darley-Usmar V, Morrow J, Roberts LJ 2nd. Formation of F2-isoprostanes during oxidation of human low-density lipoprotein and plasma by peroxynitrite. Circ Res 1995;77:335341. [PubMed: 7614720]

248. Uppu RM, Squadrito GL, Pryor WA. Acceleration of peroxynitrite oxidations by carbon dioxide. Arch Biochem Biophys 1996;327:335-343. [PubMed: 8619624]

249. Denicola A, Freeman BA, Trujillo M, Radi R. Peroxynitrite reaction with carbon dioxide/ bicarbonate: kinetics and influence on peroxynitrite-mediated oxidations. Arch Biochem Biophys 1996;333:49-58. [PubMed: 8806753]

250. Squadrito GL, Pryor WA. The nature of reactive species in systems that produce peroxynitrite. Chem Res Toxicol 1998;11:718-719. [PubMed: 9671532]

251. Gow A, Duran D, Thom SR, Ischiropoulos H. Carbon dioxide enhancement of peroxynitritemediated protein tyrosine nitration. Arch Biochem Biophys 1996;333:42-48. [PubMed: 8806752]

252. Sies H, Klotz LO, Sharov VS, Assmann A, Briviba K. Protection against peroxynitrite by selenoproteins. Z Naturforsch [C] 1998;53:228-232.

253. Roussyn I, Briviba K, Masumoto H, Sies H. Selenium-containing compounds protect DNA from single-strand breaks caused by peroxynitrite. Arch Biochem Biophys 1996;330:216-218. [PubMed: 8651699]

254. Epe B, Ballmaier D, Roussyn I, Briviba K, Sies H. DNA damage by peroxynitrite characterized with DNA repair enzymes. Nucleic Acids Res 1996;24:4105-4110. [PubMed: 8932358]

255. Briviba K, Roussyn I, Sharov VS, Sies H. Attenuation of oxidation and nitration reactions of peroxynitrite by selenomethionine, selenocystine and ebselen. Biochem J 1996;319(Pt 1):13-15. [PubMed: 8870642] 
256. Forgione MA, Cap A, Liao R, Moldovan NI, Eberhardt RT, Lim CC, Jones J, Goldschmidt-Clermont PJ, Loscalzo J. Heterozygous cellular glutathione peroxidase deficiency in the mouse: abnormalities in vascular and cardiac function and structure. Circulation 2002;106:1154-1158. [PubMed: 12196344]

257. Blankenberg S, Rupprecht HJ, Bickel C, Torzewski M, Hafner G, Tiret L, Smieja M, Cambien F, Meyer J, Lackner KJ. Glutathione peroxidase 1 activity and cardiovascular events in patients with coronary artery disease. N Engl J Med 2003;349:1605-1613. [PubMed: 14573732]

258. Bennett JS. Platelet-fibrinogen interactions. Ann N Y Acad Sci 2001;936:340-354. [PubMed: 11460491]

259. Freedman JE, Loscalzo J, Barnard MR, Alpert C, Keaney JF, Michelson AD. Nitric oxide released from activated platelets inhibits platelet recruitment. J Clin Invest 1997;100:350-356. [PubMed: 9218511]

260. Ludwig RJ, Schultz JE, Boehncke WH, Podda M, Tandi C, Krombach F, Baatz H, Kaufmann R, von Andrian UH, Zollner TM. Activated, not resting, platelets increase leukocyte rolling in murine skin utilizing a distinct set of adhesion molecules. J Invest Dermatol 2004;122:830-836. [PubMed: 15086572]

261. Kenet G, Freedman J, Shenkman B, Regina E, Brok-Simoni F, Holzman F, Vavva F, Brand N, Michelson A, Trolliet M, Loscalzo J, Inbal A. Plasma glutathione peroxidase deficiency and platelet insensitivity to nitric oxide in children with familial stroke. Arterioscler Thromb Vasc Biol 1999;19:2017-2023. [PubMed: 10446087]

262. Maddipati KR, Marnett LJ. Characterization of the major hydroperoxide-reducing activity of human plasma. Purification and properties of a selenium-dependent glutathione peroxidase. J Biol Chem 1987;262:17398-17403. [PubMed: 3693360]

263. Redondo PC, Salido GM, Rosado JA, Pariente JA. Effect of hydrogen peroxide on Ca2+ mobilisation in human platelets through sulphydryl oxidation dependent and independent mechanisms. Biochem Pharmacol 2004;67:491-502. [PubMed: 15037201]

264. Pariente JA, Camello C, Camello PJ, Salido GM. Release of calcium from mitochondrial and nonmitochondrial intracellular stores in mouse pancreatic acinar cells by hydrogen peroxide. $\mathrm{J}$ Membr Biol 2001;179:27-35. [PubMed: 11155207]

265. Moreau VH, Castilho RF, Ferreira ST, Carvalho-Alves PC. Oxidative damage to sarcoplasmic reticulum Ca2+-ATPase AT submicromolar iron concentrations: evidence for metal-catalyzed oxidation. Free Radic Biol Med 1998;25:554-560. [PubMed: 9741592] 


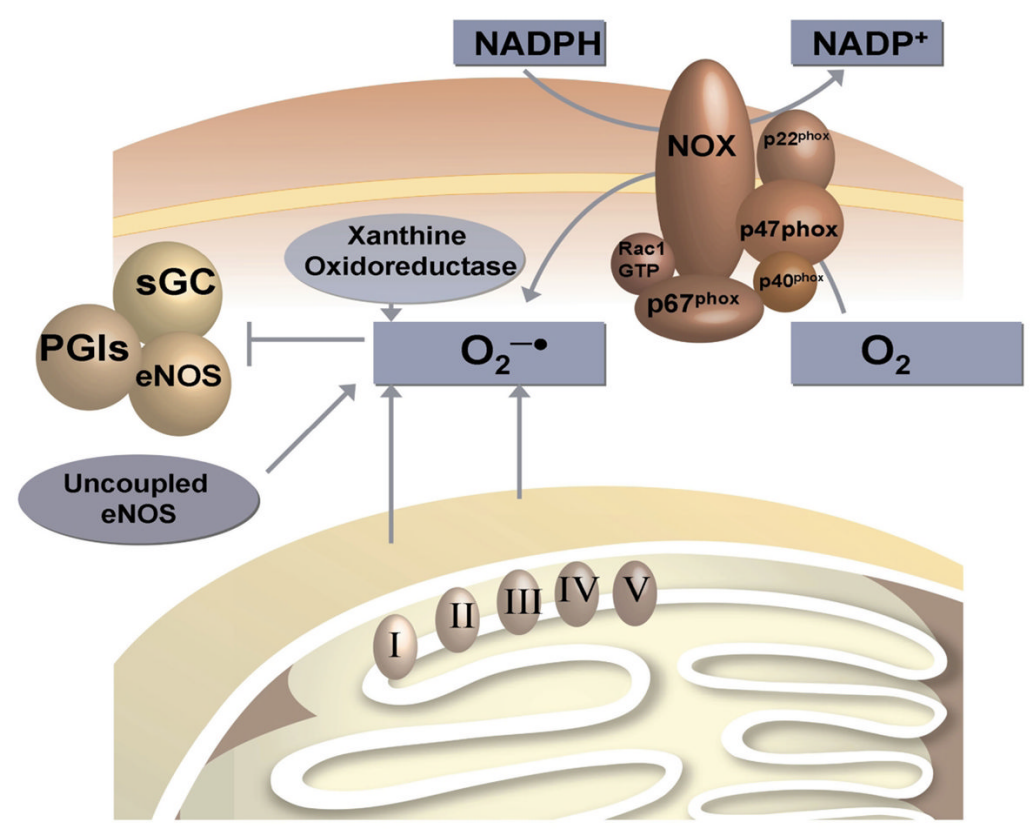

Figure 1.

Source of Superoxide Anion. The membrane-associated NAD(P)H oxidase enzyme complex catalyze the one-electron reduction of molecular oxygen using $\mathrm{NAD}(\mathrm{P}) \mathrm{H}$ as an electron donor, generating superoxide anion $\left(\mathrm{O}_{2}^{-\bullet}\right)$. The catalytic $\mathrm{b}_{558^{-}}$-type cytochrome Nox subunit is bound to $\mathrm{p} 22^{\text {phox }}$ in the plasma membrane, and they stabilize each other. The cytosolic subunits shown may also be required for full and substained activation of the complex in vascular cells. Among the other sources of $\mathrm{O}_{2}^{-\bullet}$ are the xanthine oxidoreductase enzyme system and 'uncoupled' eNOS. The mitochondrial electron transport chain produces $\mathrm{O}_{2}{ }^{-\bullet}$ by incomplete reduction of oxygen $\left(\mathrm{O}_{2}\right)$, mainly at complex I (NADH coenzyme $\mathrm{Q}$ reductase) and complex III (ubiquinol cytochrome $c$ reductase). 


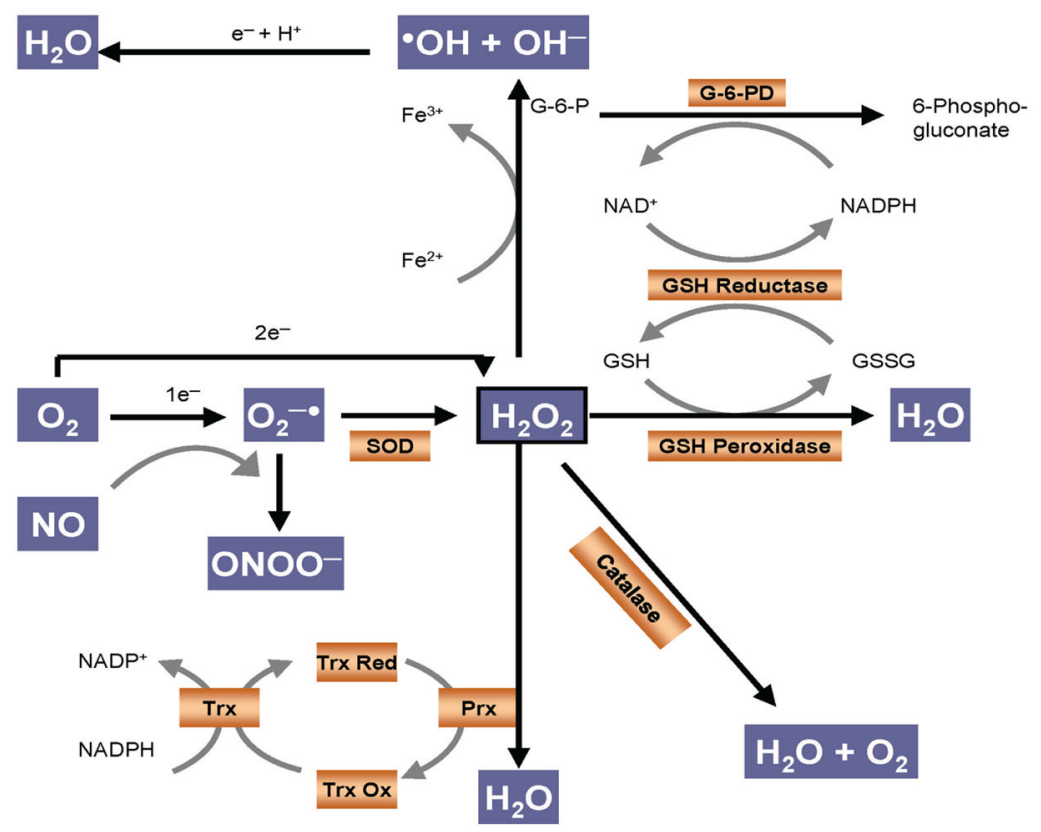

Figure 2.

Biochemical Reactions of Reactive Oxygen Species. Superoxide anion reacts with itself to form hydrogen peroxide $\left(\mathrm{H}_{2} \mathrm{O}_{2}\right)$ and oxygen $\left(\mathrm{O}_{2}\right)$ by spontaneous $\left(k=\sim 5 \times 10^{5} \mathrm{M}^{-1} \cdot \mathrm{s}^{-1}\right.$ at $\mathrm{pH}$ 7.4) and enzymatic dismutation reactions $\left(k=\sim 2 \times 10^{9} \mathrm{M}^{-1} \bullet \mathrm{s}^{-1}\right)$. Basal levels of $\mathrm{H}_{2} \mathrm{O}_{2}$ appear to regulate some signal transduction pathways, or are reduced to water $\left(\mathrm{H}_{2} \mathrm{O}\right)$ by peroxiredoxins, glutathione peroxidases, or catalase. By the metal-catalyzed Fenton reaction, $\mathrm{H}_{2} \mathrm{O}_{2}$ forms the highly reactive hydroxyl radical $\left({ }^{\circ} \mathrm{OH}\right)$, which is the strongest oxidizing agent known. Superoxide anion reacts also with nitric oxide (NO) to from peroxynitrite $\left(\mathrm{ONOO}^{-}\right)$ at the diffusion limit with a rate $\left(k=\sim 6.7 \times 10^{9} \mathrm{M}^{-1} \bullet \mathrm{s}^{-1}\right)$ that is faster than that of the superoxide dismutase (SOD) reaction. 


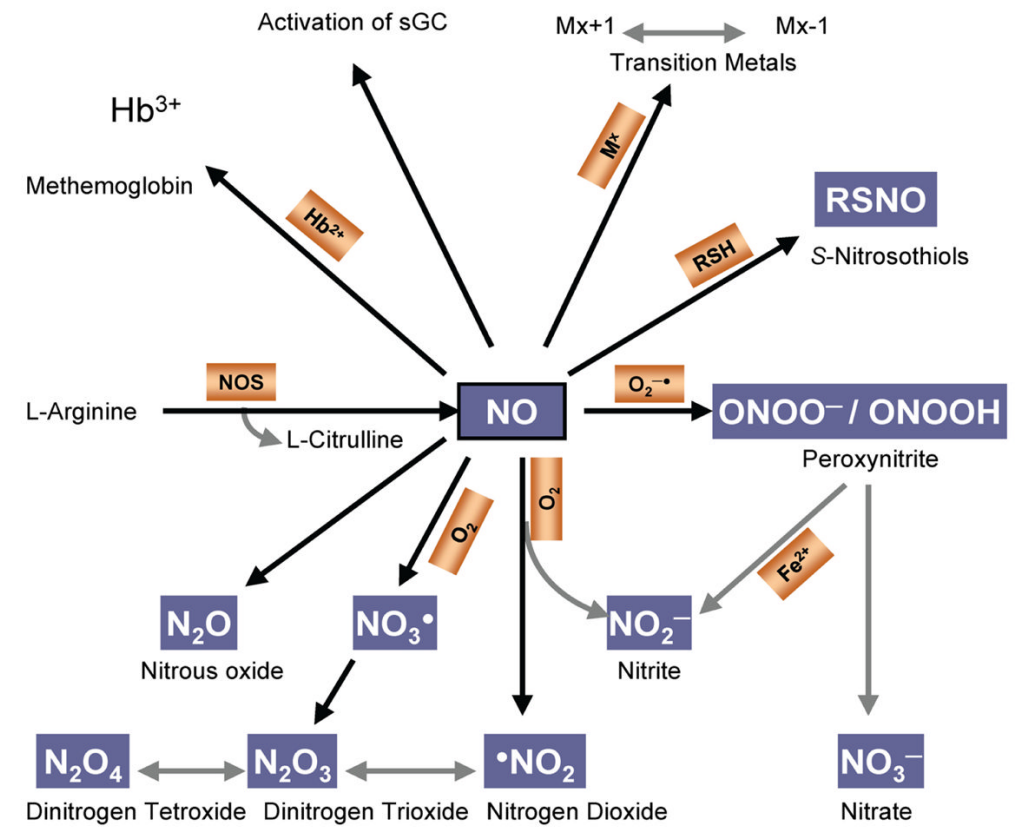

Figure 3.

Common Chemical Reactions of Nitric Oxide. Synthesized from nitric oxide synthase (NOS), using L-arginine, nitric oxide (NO) reacts with a variety of targets, such as the ferrous iron $\left(\mathrm{Fe}^{2+}\right)$ in heme moieties. In hemoglobin $\left(\mathrm{Hb}^{2+}\right)$, the conversion to ferric iron $\left(\mathrm{Fe}^{3+}\right)$ forms methemoglobin $\left(\mathrm{Hb}^{3+}\right)$. Nitric oxide may also activate soluble guanylyl cyclase (sGC) and react with transition metals $(\mathrm{M})$ to alter their valence $(\mathrm{x})$. Nitric oxide also reacts with thiol groups (RSH) to produce $S$-nitrosothiols (RSNO). At rapid rates, NO reacts with superoxide anion $\left(\mathrm{O}_{2}^{-\bullet}\right)$ to form peroxynitrite $\left(\mathrm{ONOO}^{-} / \mathrm{ONOOH}\right)$, which can form to nitrate $\left(\mathrm{NO}_{3}{ }^{-}\right)$. Nitric oxide can be reduced to nitrous oxide $\left(\mathrm{N}_{2} \mathrm{O}\right)$ or oxidized to nitrite $\left(\mathrm{NO}_{2}^{-}\right)$. Nitrite can react rapidly with oxygen, yielding nitrogen dioxide radical $\left({ }^{\circ} \mathrm{NO}_{2}\right)$, which exists in equilibrium with the potent nitrosating agents dinitrogen trioxide $\left(\mathrm{N}_{2} \mathrm{O}_{3}\right)$ and dinitrogen tetroxide $\left(\mathrm{N}_{2} \mathrm{O}_{4}\right)$. 


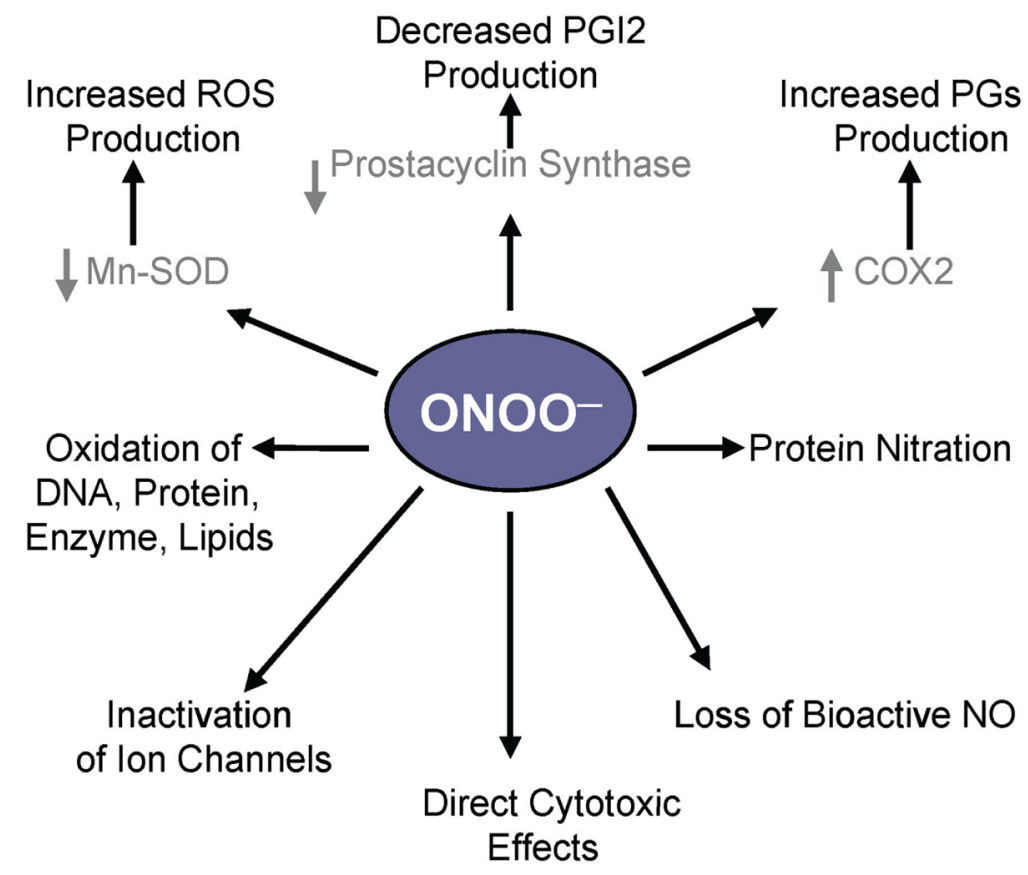

Figure 4.

Biological Consequences of Peroxynitrite Formation. Peroxynitrite formation has two important biological consequences: loss of bioactive nitric oxide (NO) and direct cytotoxic effects. Peroxynitrite and its conjugate acid can oxidize a variety of biomolecules with the consequence of protein modification or inactivation of ion channels. Peroxynitrite inactivates Mn-SOD, thereby increasing the flux of superoxide anion $\left(\mathrm{O}_{2}{ }^{-\bullet}\right)$ available to react with nitric oxide and establishing an autocatalytic spiral of increasing mitochondrial peroxynitrite formation. 
Table 1

Reactive Oxygen Species

\begin{tabular}{|c|c|c|}
\hline Oxidant & Characteristics & Function \\
\hline Superoxide Anion $\left(\mathrm{O}_{2}^{-*}\right)$ & $\begin{array}{l}\text { One-electron reduction of } \mathrm{O}_{2} \\
\text { Formed in many autooxidation reactions } \\
\text { Electron transport chain } \\
\mathrm{NAD}(\mathrm{P}) \mathrm{H} \text { oxidase } \\
\text { Mitochondrial respiration } \\
\text { Glucose oxidase } \\
\text { Xanthine oxidase } \\
\text { Cytochrome } \mathrm{P} 450 \mathrm{~s} \\
\text { Cyclooxygenase } \\
\text { Lipoxygenase } \\
\text { Aldehyde oxidase } \\
\text { Flavin dehydrogenase }\end{array}$ & $\begin{array}{l}\text { Cause oxidative damage } \\
\text { Alterations in gene transcription, } \\
\text { posttranslational protein modification } \\
\text { Changes in protein function and enzyme } \\
\text { activites } \\
\text { Release } \mathrm{Fe}^{2+} \text { from iron-sulfur proteins and } \\
\text { ferritin } \\
\text { Inactivation of NO }\end{array}$ \\
\hline Hydrogen Peroxide $\left(\mathrm{H}_{2} \mathrm{O}_{2}\right)$ & $\begin{array}{l}\text { Two-electron reduction of } \mathrm{O}_{2} \\
\text { Dismutation of } \mathrm{O}_{2}^{-} \cdot \\
\text { Xanthine oxidase } \\
\text { Glucose oxidase }\end{array}$ & $\begin{array}{l}\text { Lipid soluble } \\
\text { Freely diffuses across membranes }\end{array}$ \\
\hline Hydroxyl Radical ('OH) & $\begin{array}{l}\text { Three-electron reduction of } \mathrm{O}_{2} \\
\text { Formation via Fenton reaction } \\
\text { Decomposition of peroxynitrite }\end{array}$ & $\begin{array}{l}\text { Extremly reactive } \\
\text { Attacks most cellular components } \\
\text { Modification of amino acids, } \\
\text { carbohydrates, lipids, nucleic acids } \\
\end{array}$ \\
\hline Organic Hydroperoxide $(\mathrm{ROOH})$ & $\begin{array}{l}\text { Formed by radical reactions with cellular } \\
\text { components }\end{array}$ & Reaction with lipids and nucleobases \\
\hline $\begin{array}{l}\text { Alkoxy }\left(\mathrm{RO}^{\circ}\right) \text { and Peroxy Radicals } \\
\left(\mathrm{ROO}^{\circ}\right)\end{array}$ & $\begin{array}{l}\text { Oxygen-centered organic radicals } \\
\text { Formed in presence of oxygen by radical } \\
\text { addition to double bonds } \\
\text { Formed by hydrogen abstraction }\end{array}$ & Lipid peroxidation \\
\hline Hypochlorous Acid (HOCl) & Formed from $\mathrm{H}_{2} \mathrm{O}_{2}$ by myeloperoxidase & $\begin{array}{l}\text { Lipid soluble } \\
\text { Highly reactive } \\
\text { Oxidizes protein side chains, including } \\
\text { thiol groups, amino groups, and methionine }\end{array}$ \\
\hline Peroxynitrite $\left(\mathrm{OONO}^{-}\right)$ & $\begin{array}{l}\text { Formed in a diffusion-controlled } \\
\text { reaction between } \mathrm{O}_{2}^{-} \text {and } \mathrm{NO}^{\circ} \\
\text { Protonation forms peroxynitrous acid, } \\
\text { which can undergo homolytic cleavage to } \\
\text { form hydroxyl radical and nitrogen dioxide }\end{array}$ & $\begin{array}{l}\text { Lipid soluble } \\
\text { Highly reactive } \\
\text { Uncouple NOS by oxidizing cysteines } \\
\text { involved in the zinc-thiolate cluster }\end{array}$ \\
\hline
\end{tabular}


Biological Antioxidants

Table 2

\begin{tabular}{|c|c|c|}
\hline Antioxidant & Characteristics & Function \\
\hline Ascorbic Acid (Vitamin C) & $\begin{array}{l}\text { Dietary sources } \\
\text { Reduced form by maintained glutathione } \\
\text { Reduction catalyzed by protein disulfide } \\
\text { isomerase and glutaredoxins }\end{array}$ & $\begin{array}{l}\text { Water soluble monosaccharide } \\
\text { Free radical formation via Fenton reaction } \\
\text { Protects vitamin E and GSH against oxidation }\end{array}$ \\
\hline alpha-Tocopherol (Vitamin E) & Dietary sources & $\begin{array}{l}\text { Lipid-soluble } \\
\text { Chain-breaking radical scavenger family } \\
\text { Reaction with lipid radicals } \\
\text { Modulation of several enzymes in signal } \\
\text { transduction }\end{array}$ \\
\hline Glutathione (GSH) & $\begin{array}{l}\text { Synthesized from cysteine, glutamate, glycine } \\
\text { Recycled by reduction of GSSG by } \\
\text { glutathione reductase }\end{array}$ & $\begin{array}{l}\text { Major low-molecular-weight cysteine- } \\
\text { containing peptide } \\
\text { Eliminating lipid hydroperoxides and } \mathrm{H}_{2} \mathrm{O}_{2} \text { as } \\
\text { a reducing co-substrate for glutathione } \\
\text { peroxidases } \\
\text { Involved in protein folding and ascorbate } \\
\text { metabolism and generally preventing protein } \\
{ }^{-} \mathrm{SH} \text { groups from oxidation and cross-linkage }\end{array}$ \\
\hline Superoxide Dismutase (SOD) & $\begin{array}{l}\text { Three isoforms } \\
\text { Contain metal ion cofactors (copper, zinc, } \\
\text { manganese, iron) }\end{array}$ & Convert $\mathrm{O}_{2}^{-\cdot}$ to $\mathrm{H}_{2} \mathrm{O}_{2}$ and molecular oxygen \\
\hline Catalase & Localized to peroxisomes & $\begin{array}{l}\text { Reduction of } \mathrm{H}_{2} \mathrm{O}_{2} \text { to } \mathrm{H}_{2} \mathrm{O} \text { using either an iron } \\
\text { or manganese cofactor }\end{array}$ \\
\hline Peroxiredoxins (Prx) & $\begin{array}{l}\text { Three subgroups } \\
\text { Redox-active cysteine oxidized to a sulfenic } \\
\text { acid }\end{array}$ & $\begin{array}{l}\text { Reduction of } \mathrm{H}_{2} \mathrm{O}_{2} \text { to } \mathrm{H}_{2} \mathrm{O} \\
\text { May remove thiyl radicals, causing }{ }^{-} \mathrm{SH} \text { group } \\
\text { oxidation }\end{array}$ \\
\hline Thioredoxin & $\begin{array}{l}\text { Redox-sensitive signaling functions } \\
\text { Expression induced by oxidative stress }\end{array}$ & $\begin{array}{l}\text { Reduction of disulfides in protein, peptides, } \\
\text { and GSSG } \\
\text { Directly reducing ROS }\end{array}$ \\
\hline Glutathione Peroxidase & Five isoforms & $\begin{array}{l}\text { Reduction of } \mathrm{H}_{2} \mathrm{O}_{2} \text { to } \mathrm{H}_{2} \mathrm{O} \\
\text { Reduction of organic hydroperoxides } \\
\text { Using GSH as a reductant } \\
\text { Reduction of peroxynitrite }\end{array}$ \\
\hline Heme Oxygenase & Two isoforms & $\begin{array}{l}\text { Production of biliverdin and bilirubin } \\
\text { Degradation of free heme } \\
\text { Production of } \mathrm{CO}\end{array}$ \\
\hline
\end{tabular}

